\title{
Methodological Discussion of the Income Measure in the European Social Survey Round 1
}

\author{
Jürgen H.P. Hoffmeyer-Zlotnik and Uwe Warner ${ }^{1}$
}

\begin{abstract}
During the last decade, the number of cross-national and cross-cultural empirical research has increased; at the same time the need for comparative survey data grew considerably. Also more and more politicians and policy decision makers are looking across the national and cultural borders of their countries.

Looking at the question of total net household income, we discus advantages and weaknesses of an input harmonized social survey. We demonstrate the impact of the national social, economic and legal particularities on the answering behavior of the surveyed respondent by comparing across countries the interview outcomes from the European Social Survey (ESS) and the European Community Household Panel (ECHP). ESS used a crude measurement of the total net household income interviewing only one randomly selected household member. ECHP surveyed all persons living in a sampled household and asked all income sources and components of the respondents and the household. In this paper we use ECHP as a reference showing the most accurate method to measure income, and compare this with the interview results of ESS.

For comparative social surveys we propose a set of questions on income that takes into account the national circumstances. We get comparable data across countries reflecting the national tax systems, the particular practices in the earning structures and the national habits in summing up the different income components. We expect that such a new fieldwork instrument integrated into the data production of cross-national surveys may increase the analytical power of the comparative socio-demographic variable "total net household income".
\end{abstract}

\footnotetext{
${ }^{1}$ Jürgen H.P. Hoffmeyer-Zlotnik is senior researcher and Senior Project Consultant at ZUMA, Mannheim; Uwe Warner is senior researcher at CEPS/INSTEAD, Differdange.

This paper is supported by the national science foundation of Luxembourg (FNR) by the contract No. FNR/04/MA6/10, the infrastructures and the "Luxembourg Comparative Data Bases and Archive" of CEPS/INSTEAD at Differdange, Luxembourg
} 


\section{Introduction}

Different surveys use different strategies to arrange the questionnaires and different accuracy to construct the income questions. This degree of precision depends on the research interest and the aims of the study.

Market research is interested in categorizing the purchasing power of a household and classifies the households into consumer groups. They focus on classes of income size and therefore they do not give a precise definition of income and they make no distinction between several surveyed population groups. In Germany, they ask for the monthly net income and they give a general instruction in the question wording. The answers are income brackets. In case the interviewed person refuses to answer, the interviewer often takes the freedom to estimate the household's income.

Holst (2003: 380) illustrates in comparative perspective the use of the ESOMAR scale on economic status based on ten long-lasting consumer goods as a proxy scale for income. "The underlying idea apparently is that the possession of these goods is an indicator of the household's economic purchasing power and the accumulation of these goods can be interpreted in terms of relative distance."

Economic and socio-economic research is studying income distribution and the dynamics of changes in the economic situation of the respondent. The research question on how the total income is composed by it components and changes of the income types are of interest. Therefore a precise measurement of income is needed. The several types of income are defined in detail and separated by their sources and types. Specific population groups and/or income recipients are interviewed according their characteristics. For a well-defined time period (e.g. monthly) gross and net income are asked through open questions and all other monetary resources of all persons living in the household, as well as payments to the household per se are asked for. In general the answer is given in gross and/or net amount (European Commission 1996).

For studies of income inequality comparisons across countries Cowell, Litchfield and Mercader-Prats (1999) identify four types of problems having an impact on the analyses of economic inequality. They list $1^{\text {st }}$ the data collection period weekly vs. annual income amounts, $2^{\text {nd }}$ the accuracy of individual responses according to the time gap between the income reference period and the time of the interview, $3^{\text {rd }}$ the detail of the income questionnaires, and $4^{\text {th }}$ the misreporting of incomes by self-employed respondents and the under-reporting of capital income. To overcome these problems the authors propose two main strategies. The first technique is the imputation of extra income values to these households with no or very low income information, the second is to separate the self-employed population from the non-self-employed. Also Cowell and Victoria-Feser (1996: 
78) propose to quantify the "qualitative" aspects of monetary income estimators by applying the Influence Function, "a measure of robustness which indicates the extent to which an estimator is influenced by an infinitesimal amount of "errors"'.

Social research uses income as a socio-economic indicator on social stratification and inequality. From this point of view the knowledge of size classes of the household income is sufficient. But social research defines the various income types and formulates separate questions for different population groups, for example the wording of the income question differs for the self-employed and for employees. In Germany, the monthly net income is surveyed by an open question and for non response reduction a second question with income brackets is given to the interviewee in case of refusing the open question (Statistisches Bundesamt 2004).

From 1994 to 2001 the European Community Household Panel (ECHP) was carried out in 14 countries of the European Community ${ }^{2}$. The ECHP surveys all types of incomes coming from all national possible sources. The fieldwork instrument mentions all items; so that the respondent can remember his/her amount of incomes during the previous calendar year.

The person, answering the ECHP questionnaire, is asked questions about his/her individual income; all household members (as long they belong to the panel sample) are interviewed. Being requested for his/her own monetary items, the respondent can react as an expert on his/her own.

The household questionnaire of ECHP is filled in by the most reliable household member. This is in general the person in charge of the accommodation or the main bread winner of the household. Also here the respondent can answer the household questions as an expert, because this reference person has the knowledge and the information about the household's financial situation.

The European Social Survey (ESS) collects data in 21 European countries ${ }^{3}$. The ESS asks on income two questions: the main source of the income of the household and the categorized household's total net income. To measure socioeconomic status and stratification, this operationalization of the income item is sufficient for social research.

The respondent has no detailed explication about the income components and the questionnaire of ESS offers no help to recall the different elements, which the respondent has to sum up.

The person eligible for the ESS interview is selected randomly among the household members. Therefore the knowledge of the household reference person about the financial situation of the entire household can vary. The less informed respondent underestimates the total net household income.

2 Denmark, The Netherlands, Belgium, France, Ireland, Italy, Greece, Spain, Portugal, Austria, Finland, Germany, Luxembourg, United-Kingdom.

${ }^{3}$ Austria, Belgium, Switzerland, Czech Republic, Germany, Denmark, Spain, Finland, United Kingdom, Greece, Hungary, Ireland, Israel, Italy, Luxembourg, The Netherlands, Norway, Poland, Portugal, Sweden, Slovenia. 
The fieldwork instrument of ESS does not recall the detailed sources and/or types of income. It is obvious that the interviewed person forgets income components in his/her adding up the numerous possible sources and the other household members. Small, regular amounts and unusual, larger amounts, and amount not known to the respondent create an underestimation and a measurement error.

Near cash and non cash incomes are in general not included in the sum of total net household income.

In this paper we use ECHP as a reference showing the most accurate method to measure income. We consider the "total net household income" variable of ECHP also as a benchmark for the value of the household income question of ESS. Our interest is to elaborate the divergences of both measures and to illustrate the reasons for the differences in the outcomes. We are not interested to show how to use the ESS income variable in cross national comparative research. Therefore the main focus is the discussion of the survey instrument used to assess total net household income in social surveys.

A close look we have on Germany, United Kingdom, Italy, and Luxembourg; for demonstrating some results we also use results from Poland, Finland, and Portugal.

The second chapter introduces the used surveys.

The third chapter describes the fieldwork instruments used to measure income.

The forth chapter presents the first, descriptive analysis for Germany, United Kingdom, Italy, and Luxembourg.

The fifth chapter discusses the quality of the income measurement and turns the light on characteristics having an impact on the responses: 5.1. is the impact of household definition and size, 5.2. the impact of the respondent's family relation to the main income earner, 5.3. the impact of the main income sources, 5.4 the income composition and 5.5. is the influence of the respondent's cognitive capability to remember the income.

The sixth chapter develops a proposal for measuring household income for cross country comparison in social survey research.

The seventh chapter gives recommendations for the development of fieldwork instruments measuring household income for cross-national comparative data.

\section{Description of the used surveys}

The European Social Survey (ESS) is a pan-European cross sectional time series running every two years. During the 2002 surveys, 23 countries participated and collected information on people's social attitudes, beliefs in values, social and political behavior.

In each participation country, the survey design of ESS is a random sample with a known inclusion probability of the selected contact person eligible for the 
interview. The number of sampled contacts depends on the size of the country. The item non responds varies over countries: in Italy 637 contact persons answered the income question and the maximum was reached in Germany with 2336 units responding the income item. Only on household member aged 16 and over is asked; this person also answers the question about the household situation and also the questions concerning the total net household income.

We use the data base version published in Feb. 03, 2004. For 21 countries 40,856 responses are included into the data-base.

The European Community Household Panel (ECHP) is a longitudinal study coordinated by Eurostat. The major aims of ECHP are to provide micro-data on household and person level about the income, the monetary well-being and the dynamics of the economic situation in the European community and its member states.

This panel study traces the same individuals and households year by year; and all household members aged 15 years and over are interviewed by a person questionnaire. The person questionnaire of the $8^{\text {th }}$ wave asks for 50 different income objects. One member of the contacted household is surveyed by a household questionnaire. The household questionnaire of the $8^{\text {th }}$ wave covered five income items received by the household.

To compare the ESS survey outcomes we use the ECHP user data base version April 2004 available to the academic community. The $8^{\text {th }}$ wave's interviews are carried out in 2001 and refer to the income reference year 2000.

In 15 EU countries 59,852 households with 121,122 members are surveyed during 2001.

In three countries the data of ECHP are constructed from the existing national panel studies. The ex post harmonization is discussed in various working papers and publications of CHINTEX (http://www.destatis.de/chintex/res_res/workshop2.htm).

For Germany, the $8^{\text {th }}$ wave of ECHP was created using the data of the German Socio-Economic Panel (SOEP) carried out by the Deutsche Institut für Wirtschaftsforschung, Berlin. Based on answers collected for the SOEP, the data were transformed into the variables and items necessary for ECHP using the common variable definitions and coding schemes.

The ECHP wave 8 is built from 5,563 German households where 10,624 persons are living.

For the United Kingdom, the $8^{\text {th }}$ wave ECHP data are based on the British Household Panel Survey (BHPS). is carried out by the ESRC UK Longitudinal Studies Centre with the Institute for Social and Economic Research at the University of Essex.

The $8^{\text {th }}$ wave of the ECHP database contains 4,819 households with 8,521 members from the BHPS. 
The Panel Socio-Economique Liewen zu Lëtzebuerg (PSELL) is a social and economic panel study interviewing individuals and households living in Luxembourg. PSELL became part of the European Community Household Panel (ECHP) and 4,916 individuals living in 2,428 households are integrated into the $8^{\text {th }}$ wave of the ECHP.

\section{The income questions}

The ESS question wording is: "... if you add up the income from all sources, which letter describes your household's total net income? If you don't know the exact figure, please give an estimate. Use the part of the card that you know best: weekly, monthly or annual income." (ESS 01/08/2002: F30) The interviewer hands over to the respondent a show card with answer categories:

CARD 56

\begin{tabular}{|c|c|c|c|c|}
\hline & \multicolumn{3}{|c|}{ YOUR $\underline{\text { HOUSEHOLD INCOME }}$} & \\
\hline & $\begin{array}{l}\text { Approximate } \\
\text { WEEKLY }\end{array}$ & $\begin{array}{l}\text { Approximate } \\
\text { MONTHLY }\end{array}$ & $\begin{array}{l}\text { Approximate } \\
\text { ANNUAL }\end{array}$ & \\
\hline $\mathbf{J}$ & Less than $€ 40$ & Less than $€ 150$ & Less than $€ 1800$ & $\mathbf{J}$ \\
\hline $\mathbf{R}$ & $€ 40$ to under $€ 70$ & $€ 150$ to under $€ 300$ & $€ 1800$ to under $€ 3600$ & $\mathbf{R}$ \\
\hline C & $€ 70$ to under $€ 120$ & $€ 300$ to under $€ 500$ & $€ 3600$ to under $€ 6000$ & C \\
\hline M & $€ 120$ to under $€ 230$ & $€ 500$ to under $€ 1000$ & $€ 6000$ to under $€ 12000$ & M \\
\hline $\mathbf{F}$ & $€ 230$ to under $€ 350$ & $€ 1000$ to under $€ 1500$ & $€ 12000$ to under $€ 18000$ & $\mathbf{F}$ \\
\hline s & $€ 350$ to under $€ 460$ & $€ 1500$ to under €2000 & $€ 18000$ to under $€ 24000$ & $\mathrm{~s}$ \\
\hline K & $€ 460$ to under $€ 580$ & $€ 2000$ to under $€ 2500$ & $€ 24000$ to under $€ 30000$ & K \\
\hline $\mathbf{P}$ & $€ 580$ to under $€ 690$ & $€ 2500$ to under $€ 3000$ & $€ 30000$ to under $€ 36000$ & $\mathbf{P}$ \\
\hline D & $€ 690$ to under $€ 1150$ & $€ 3000$ to under $€ 5000$ & $€ 36000$ to under $€ 60000$ & D \\
\hline H & $€ 1150$ to under $€ 1730$ & $€ 5000$ to under $€ 7500$ & $€ 60000$ to under $€ 90000$ & $\mathrm{H}$ \\
\hline $\mathbf{U}$ & $€ 1730$ to under $€ 2310$ & $€ 7500$ to under $€ 10000$ & $€ 90000$ to under $€ 120000$ & U \\
\hline $\mathbf{N}$ & $€ 2310$ or more & $€ 10000$ or more & $€ 120000$ or more & $\mathbf{N}$ \\
\hline
\end{tabular}

(Source: ESS 01/08/2002: Card56)

Figure 1: Show card from ESS.

Additional explanations are given to the interviewer at the end of the "project instructions": At the income question "you should obtain the total net income of the household from all sources, that is, after tax. Income includes not only earnings but state benefits, occupational and other pensions, unearned income such as interest from savings, rent, etc. 
We want figures after deductions of income tax, national insurance, contributory pension payments and so on. The questions refer to current level of income or earnings or, if that is convenient, to the nearest tax or other period for which the respondent is able to answer. The respondent is given a show card that enables them to choose between their weekly, monthly or annual income, whichever they find easiest. They will then give you the letter that corresponds to the appropriate amount. This system is designed to reassure the respondent about the confidentiality of the information they are giving." (ESS 15/07/2002: 21)

A very general sentence of the project instructions deals with the item non response. "... there are some questions where people are asked to give information that may be regarded as sensitive. Some respondents may feel uneasy about giving information on their voting behavior or income, for example. If so, this should be coded as 'refusal'". (ESS 15/07/2002: 17)

Just before measuring the income amount, ESS asks about the main income source of the household: "Please consider the income of all household members and any income which may be received by the household as a whole. What is the main source of income in your household? Please use this card." (ESS 01/08/2002: F29)

\title{
CARD 55
}

\author{
Wages or salaries \\ Income from self-employment or farming \\ Pensions \\ Unemployment/redundancy benefit \\ Any other social benefits or grants \\ Income from investment, savings, insurance or \\ property \\ Income from other sources
}

(Source: ESS 01/08/2002: Card55)

Figure 2: Show card from ESS.

In ESS, a randomly selected member of the household answers these questions on household items.

The ECHP measures income by using a sixteen page long section in the person's questionnaire. Every member (fifteen years and over) of an eligible household answers the person questionnaire. The first approach to income is a monthly calendar about the labor force status of the respondent. For the year prior to the year of the interview, month by month the employment situation is collected. (e.g. the eighth wave interviews carried out in 2001 ask about the 
situation in 2000). The second step forward to the incomes is a sequence on having or not various income sources listed in the questionnaire. After this the respondent is asked to give net and/or gross amounts of his/her income details during the income reference year, which is the year prior to the survey year.

This list summarizes the income details mentioned in the ECHP interviews: as an employee:

income including both casual or temporary work and any regular work: wage, salary etc./ (normal) earning per month.

extra payments for overtime work or commissions or tips

13th salary, 14th salary, holiday pay or allowance

profit sharing, bonus, lump-sum payment, company shares

self-employment:

pre-tax-profit

over all profit

income from agriculture or a secondary or casual job

income and benefits from sources other than work:

benefit related to unemployment, job creation or training

insurance benefit

placement, resettlement, rehabilitation benefits

pensions:

old-age pension

widows pension

Orphan's pension/allowance

child allowance

allowance for care of invalid dependants

maternity allowance

birth allowance

unmarried mother's allowance

deserted wife's allowance

other family-related benefits

any benefit relating to sickness or invalidity

compensation for occupational accidents and diseases

scholarships, study grants

private transfer:

financial support from relatives, friends or other persons outside your household

capital:

income from capital or investment

reimbursement:

reimbursements for income tax paid in previous years

One household member, considered as a reference person for the whole household, is also surveyed by a household questionnaire. Five pages of this 
questionnaire deal with incomes of the household. "Please consider the income of all household members and any income which may be received by the household as whole: Which of the following sources does your household have at present." (Question 27 of the $8^{\text {th }}$ wave, Eurostat DOC PAN 159/00) The given income sources are:

- Wages or salaries,

- Income from self-employment or farming,

- Pensions,

- Unemployment/redundancy benefits,

- Any other social benefits or grants,

- Income from investment, savings, insurance or property,

- Income from other sources.

For this list a yes/no answer is required.

Now follows the question about the "largest source of income" The answer categories is built from the above mentioned list.

Question 28 of the $8^{\text {th }}$ wave questionnaire asks "If you add up the income from all sources, do you know what is your household total net income per month?". The possible answers are "Yes, I know the total net income per month" and "No, I don't know the total net income per month". If yes, the questionnaire continues "What is your household's total net income per month? If you don't know the exact figure, please give an estimate" People with the no-response on question 28 arrive at question 28a: "Perhaps you can provide the approximate range. Is the household's net monthly income ..." (Eurostat DOC PAN 159/00) The ranges for the answers are: less than 500Euro, 500 to under 1,000 Euro, 1,000 to under 1,500 Euro, 1,500 to under 2,000 Euro, 2,000 to under 2,500 Euro, 2,500 to under 3,000 Euro, 3,000 to under 5,000 Euro, 5,000 or more per month.

The question 32 of the household questionnaire focus' the interest on “... some more specific information about the components of your total household income. ... The following questions relate to kind of income which normally is householdrelated, i.e. not assigned to individual household members." (Eurostat DOC PAN $159 / 00)$

These income components during the income reference year are:

- Social assistance payment (cash assistance)

- Non-cash assistance from the welfare office

- Income from renting property

- Inherit of property or capital, a gift or lottery winnings.

Because of this sophisticated strategy to ask for numerous incomes, to remind the respondent on probable income sources and components and last not least to ask all members of the household aged 15 years and over, we assume that the ECHP income information covers the social-economic reality. 


\section{First analysis}

From ESS we use the categorical variable "household's total net income, all sources" (HINCTNT). We kept the income brackets from the ESS fieldwork instrument on an annual basis: $1=$ less than $1,800 €, 2=1,800 €$ to under 3,600€, $3=$ $3,600 €$ to under $6,000 €, 4=6,000 €$ to under $12,000 €, 5=12,000 €$ to under $18,000 €$, $6=18,000 €$ to under $24,000 €, 7=24,000 €$ to under $30,000 €, 8=30,000 €$ to under $36,000 €, 9=36,000 €$ to under $60,000 €, 10=60,000 €$ to under $90,000 €, 11=$ $90,000 €$ to under $120,000 €, 12=120,000 €$ or more.

Preparing the ECHP data for our paper, we exploit the ECHP User Data Base. The continuous variable "total net household income (detailed, NC, total year prior to the survey)" (hi100) is transferred into Euros as common currency. Then we recode the amount into the twelve response categories of ESS.

Table 1: Number and percent of valid cases for the ECHP User Data Base variable "total net household income (detailed, NC, total year prior to the survey)" of wave 8 and for the ESS variable "household's total net income, all sources".

\begin{tabular}{|c|cc|c|c|}
\hline & \multicolumn{2}{|c|}{ ESS } & \multicolumn{2}{c|}{$\begin{array}{c}\text { ECHP } \\
\text { valid cases }\end{array}$} \\
valid cases \\
Country & $\mathrm{N}$ & Percent & $\mathrm{N}$ & Percent \\
\hline Austria & 1,472 & $65,2 \%$ & 2,200 & $86,5 \%$ \\
Belgium & 1,509 & $79,5 \%$ & 1,857 & $78,6 \%$ \\
Switzerland & 1,600 & $78,4 \%$ & & \\
Czech Republic & 988 & $72,6 \%$ & & \\
Germany & 2,336 & $80,0 \%$ & 4,675 & $84,0 \%$ \\
Denmark & 1,291 & $85,7 \%$ & 1,976 & $86,6 \%$ \\
Spain & 1,035 & $59,9 \%$ & 4,379 & $88,2 \%$ \\
Finland & 1,791 & $89,6 \%$ & 3,015 & $96,8 \%$ \\
United Kingdom & 1,784 & $86,9 \%$ & 4,147 & $86,1 \%$ \\
Greece & 1,842 & $71,8 \%$ & 3,484 & $89,0 \%$ \\
Hungary & 1,474 & $87,5 \%$ & & \\
Ireland & 1,742 & $85,1 \%$ & 1,574 & $89,4 \%$ \\
Israel & 1,945 & $77,8 \%$ & & \\
Italy & 637 & $52,8 \%$ & 4,583 & $81,8 \%$ \\
Luxembourg & 972 & $62,6 \%$ & 2,408 & $99,2 \%$ \\
Netherlands & 2,051 & $86,8 \%$ & 4,332 & $89,3 \%$ \\
Norway & 1,972 & $96,9 \%$ & & \\
Poland & 1,783 & $84,5 \%$ & & \\
Portugal & 1,053 & $69,7 \%$ & 4,042 & $87,6 \%$ \\
Sweden & 1,866 & $93,3 \%$ & & \\
Slovenia & 1,251 & $82,4 \%$ & & \\
France & & & 4,646 & $86,9 \%$ \\
\hline
\end{tabular}

Source: ECHP UDB version April 2004, own calculations. 
The two data sets, the ECHP and the ESS data we use unweighted, because we are interested on the respondents behavior in the interview situation and on the outcomes of the interview communication. Therefore the presented figures can not explain income inequality, poverty or well-being in the observed countries, because we applied no correction for sampling errors, systematic non response bias and we made no use of extrapolation factors taking into account the different country sizes.

The item non response of the ECHP household income items varies between $10 \%$ and 20\%; only Luxembourg and Finland have a smaller amount missing information. In case of non response by the interviewees, Eurostat replaced the missing values by imputations (cf. Spiess and Goebel 2003). This seems to be the most reasonable method to complete the income variable for cases with missing values.

At the ESS, the item non response for this variable varies over the countries between $3 \%$ in Norway and $47 \%$ in Italy. In Luxembourg $37 \%$ of the respondents refuse to give the total net income of the household or they are not able to answer this question because they do not know the household's income amount. In Germany the survey reached an item non-response of $20 \%$, and in the United Kingdom $13 \%$ of the surveyed persons did not answer this question. Cases with missing information are not replaced by imputation.

Between $10 \%$ and $50 \%$ of the cases have no information on the income item. They can not be replaced in cross sectional surveys, because additional necessary information about the non respondents is not available for imputation.

Also, it seems to the respondents, that ECHP is an "official" survey carried out by the national statistical agencies. The ESS appears as a less important academic social survey.

Tables 2 to 6 illustrate the differences comparing the categorized income variables in ECHP8 and ESS. The lower and the higher income groups overestimate the income in ESS, except in Luxembourg the upper categories underestimate their household income.

Table 2: Mode and median of categorized annual income by survey in selected countries.

\begin{tabular}{|c|c|c|c|c|c|c|c|c|}
\hline Survey & \multicolumn{2}{|c|}{ Germany } & \multicolumn{2}{|c|}{ United Kingdom } & \multicolumn{2}{|c|}{ Italy } & \multicolumn{2}{|c|}{ Luxembourg } \\
\hline & Mode & Median & Mode & Median & Mode & Median & Mode & Median \\
\hline ESS & 6 & 7 & 9 & 7 & 4 & 6 & 9 & 8 \\
\hline ECHP8 & 9 & 7 & 9 & 7 & 5 & 5 & 9 & 9 \\
\hline
\end{tabular}

Source: ESS 2002 version Feb. 2004, ECHP UDB version April 2004 own calculations. 
In the following we describe briefly the household income situation reported in both surveys for Germany, United Kingdom, Italy and Luxembourg:

\section{Germany}

In Germany, $3.7 \%$ of the ESS respondents tick the lowest three income categories (up to $6000 €$ per year), the ECHP answers of the wave 8 add up to $1.8 \%$ of the households having the lowest income categories.

$47 \%$ of the households surveyed in the ESS have an annul income up to $24,000 €$, this are $5 \%$ points more then households answering the ECHP8 questionnaire.

Table 3: Cumulative frequencies of total net household income for Germany.

\begin{tabular}{|r|c|r|r|}
\hline \multicolumn{2}{|c|}{ income categories } & ESS & ECHP8 \\
\hline $1:$ & $-1,800$ & 0.6 & 0.2 \\
$2:$ & $1,800-3,600$ & 1.6 & 0.7 \\
$3:$ & $3,600-6,000$ & 3.7 & 1.8 \\
$4:$ & $6,000-12,000$ & 12.8 & 11.1 \\
$5:$ & $12,000-18,000$ & 29.2 & 26.0 \\
$6:$ & $18,000-24,000$ & 47.6 & 42.2 \\
$7:$ & $24,000-30,000$ & 64.5 & 60.6 \\
$8:$ & $30,000-36,000$ & 76.4 & 74.7 \\
$9:$ & $36,000-60,000$ & 92.3 & 96.0 \\
$10:$ & $60,000-90,000$ & 97.8 & 99.3 \\
$11:$ & $90,000-120,000$ & 99.1 & 99.7 \\
$12:$ & $120,000+$ & 100.0 & 100.0 \\
\hline
\end{tabular}

Source: ESS 2002 version Feb. 2004, ECHP UDB version April 2004 own calculations.

For the ESS we find the mode at the income range of 18,000 to $24,000 €$ and the median at the income group of 24,000 to $30,000 €$, for the ECHP8 the mode is the category of 36,000 to $60,000 €$ and the median is in the seventh category where the household has an annual income of 24,000 to $30,000 €$.

$16 \%$ of the ESS households have an income of 36,000 to $60,000 €, 21 \%$ of the ECHP8 households have the same monetary resource.

Looking at the upper end of the income categories, the ESS has nearly $8 \%$ of the observed households, the $8^{\text {th }}$ wave of ECHP reports $4 \%$ of the households having $60,000 €$ and more annual income. In Germany this group of households at the upper end of the income distribution is small, but comparing both surveys this population is twice as big in ESS then in ECHP8. 

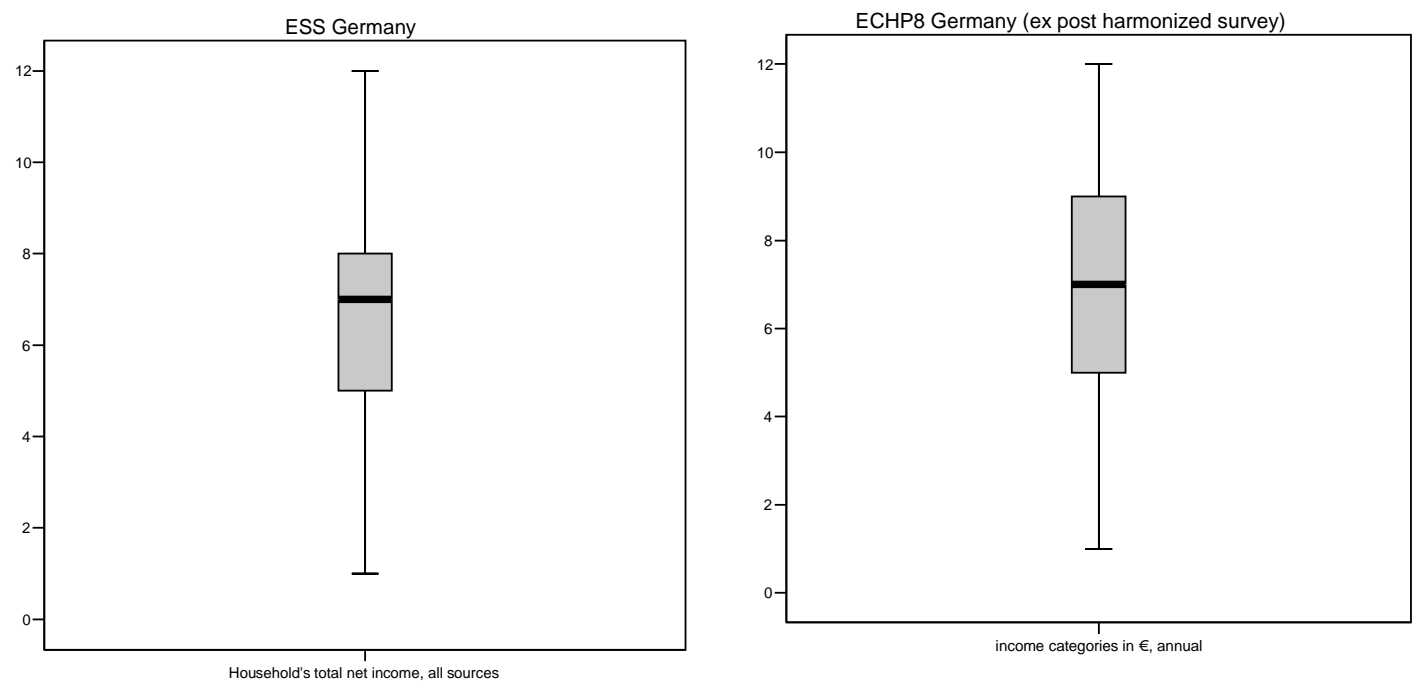

Source: ESS 2002 version Feb. 2004, ECHP UDB version April 2004 own calculations.

Figure 3: Box plot of income categories in Germany.

In Germany, the respondents of ESS overestimate there total household income at the lower $(2 \%)$ and upper extremes $(4 \%)$ of the income distribution in reference to the ECHP8. In the middle part of the income groups both surveys show nearly the same results.

\section{United Kingdom}

In ESS the income categories up to $6,000 €$ annually are three times often answered as in ECHP8 (ESS $=6 \%$ and ECHP8 $=2.2 \%$ ).

The cumulative frequencies for the categories 1 to 6 (up to 24,000€) differ about $6 \%$ between both surveys $(\mathrm{ESS}=46 \%$ and $\mathrm{ECHP} 8=40 \%)$.

ESS and ECHP8 have the median at category 7 (24,000-30,000€) and the mode at category $9(36,000 €-60,000 €)$.

$20 \%$ of the ESS respondents in the United Kingdom have a total annual net household income from 36,000 to $60,000 €$. The ECHP8 reports nearly $27 \%$ of the household in the same category.

At the upper end of the income categories $(60,000 €$ and more) both surveys differ at $5 \%$ points of the observed cases. In ESS, $16 \%$ of the surveyed households answer in these categories. In ECHP8, $11 \%$ of the households are in this income group.

In general, the upper income classes are more frequent in United Kingdom as in Germany.

Respondents, living in households with household income at the bottom or the top end of the income scale, overestimate the total household income; the interviewed persons in the middle categories underestimate their household revenue. 
Table 4: Cumulative frequencies of total net household income for United Kingdom.

\begin{tabular}{|r|c|r|r|}
\hline \multicolumn{2}{|c|}{ income categories } & ESS & ECHP8 \\
\hline $1:$ & $-1,800$ & 0.8 & 0.5 \\
$2:$ & $1,800-3,600$ & 2.6 & 1.0 \\
$3:$ & $3,600-6,000$ & 6.0 & 2.3 \\
$4:$ & $6,000-12,000$ & 22.3 & 13.6 \\
$5:$ & $12,000-18,000$ & 34.9 & 26.5 \\
$6:$ & $18,000-24,000$ & 46.1 & 39.3 \\
$7:$ & $24,000-30,000$ & 55.3 & 51.2 \\
$8:$ & $30,000-36,000$ & 64.7 & 62.3 \\
$9:$ & $36,000-60,000$ & 84.5 & 89.2 \\
$10:$ & $60,000-90,000$ & 93.7 & 97.6 \\
$11:$ & $90,000-120,000$ & 97.1 & 99.1 \\
$12:$ & $120,000+$ & 100.0 & 100.0 \\
\hline
\end{tabular}

Source: ESS 2002 version Feb. 2004, ECHP UDB version April 2004 own calculations.
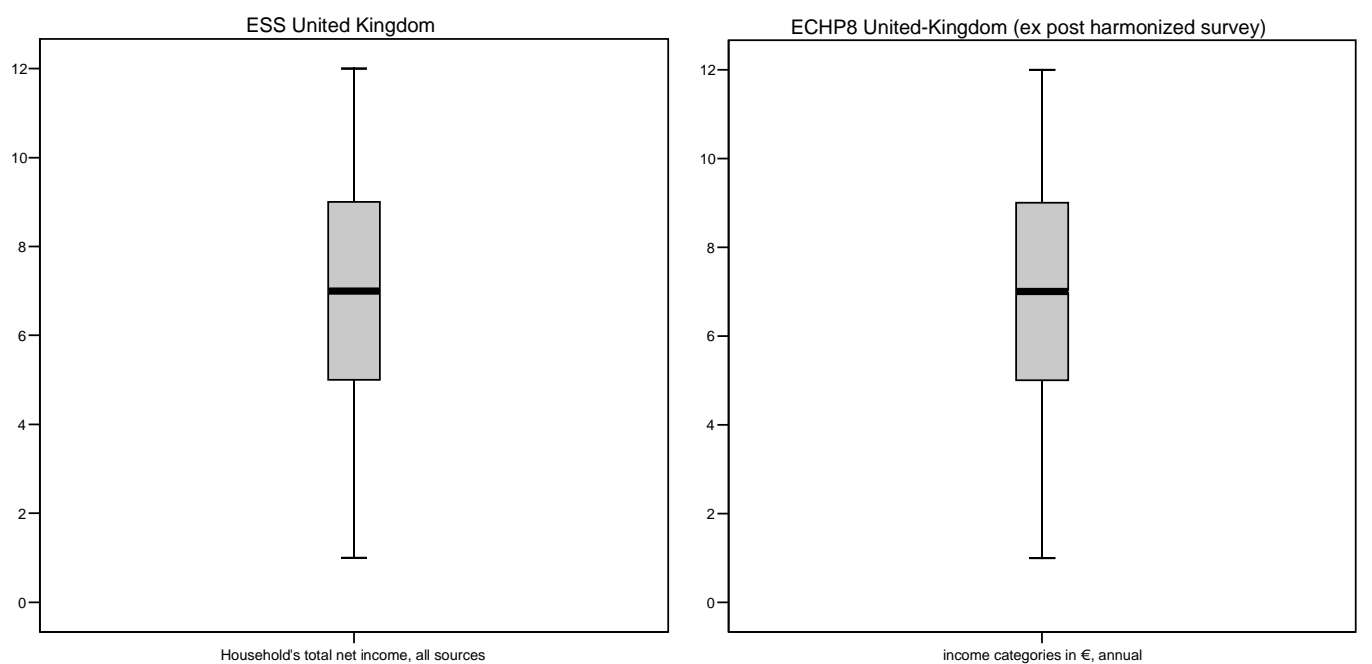

Source: ESS 2002 version Feb. 2004, ECHP UDB version April 2004 own calculations.

Figure 4: Box plot of income categories in the United Kingdom.

\section{Italy}

Up to the income category $3(3,600-6,000 €)$ the household's income do nearly not differ between ESS and ECHP8.

The cumulative responses up to category $6(18,000-24,000 €)$ differ about $2.5 \%$. In ESS $64 \%$ of the households have an income up to 24,000€, in ECHP8 $66 \%$ of the households are in the income categories 1 to 6 .

In ESS, the median of the income measure is at class 6 and in ECHP8 the income median is the category $5(12,000-18,000 €)$. 
Table 5: Cumulative frequencies of total net household income for Italy.

\begin{tabular}{|c|c|c|c|}
\hline \multicolumn{2}{|c|}{ income categories } & ESS & ECHP8 \\
\hline 1: & $-1,800$ & 0.8 & 1.0 \\
\hline 2: & $1,800-3,600$ & 2.8 & 2.2 \\
\hline 3: & $3,600-6,000$ & 8.8 & 7.0 \\
\hline 4: & $6,000-12,000$ & 28.1 & 27.6 \\
\hline 5: & $12,000-18,000$ & 47.4 & 50.5 \\
\hline 6: & $18,000-24,000$ & 63.9 & 67.3 \\
\hline 7: & $24,000-30,000$ & 77.6 & 80.9 \\
\hline 8: & $30,000-36,000$ & 84.6 & 88.7 \\
\hline 9: & $36,000-60,000$ & 95.4 & 98.5 \\
\hline 10: & $60,000-90,000$ & 98.7 & 99.6 \\
\hline 11: & $90,000-120,000$ & 99.4 & 99.9 \\
\hline 12: & $120,000+$ & 100.0 & 100.0 \\
\hline
\end{tabular}

Source: ESS 2002 version Feb. 2004, ECHP UDB version April 2004 own calculations.

In ECHP8 only $1.5 \%$ of the Italian households state a high income of $60,000 €$ and more, in ESS $4.5 \%$ of the respondents live in households with this amount.

Taking the ECHP8 as a reference, interviewees of ESS with low or high household income overestimate the amount asked in the survey. Respondents in the middle categories of this monetary item underestimate the total net household income. In general, we find small differences in the categorized measurement of household income between the two studies.
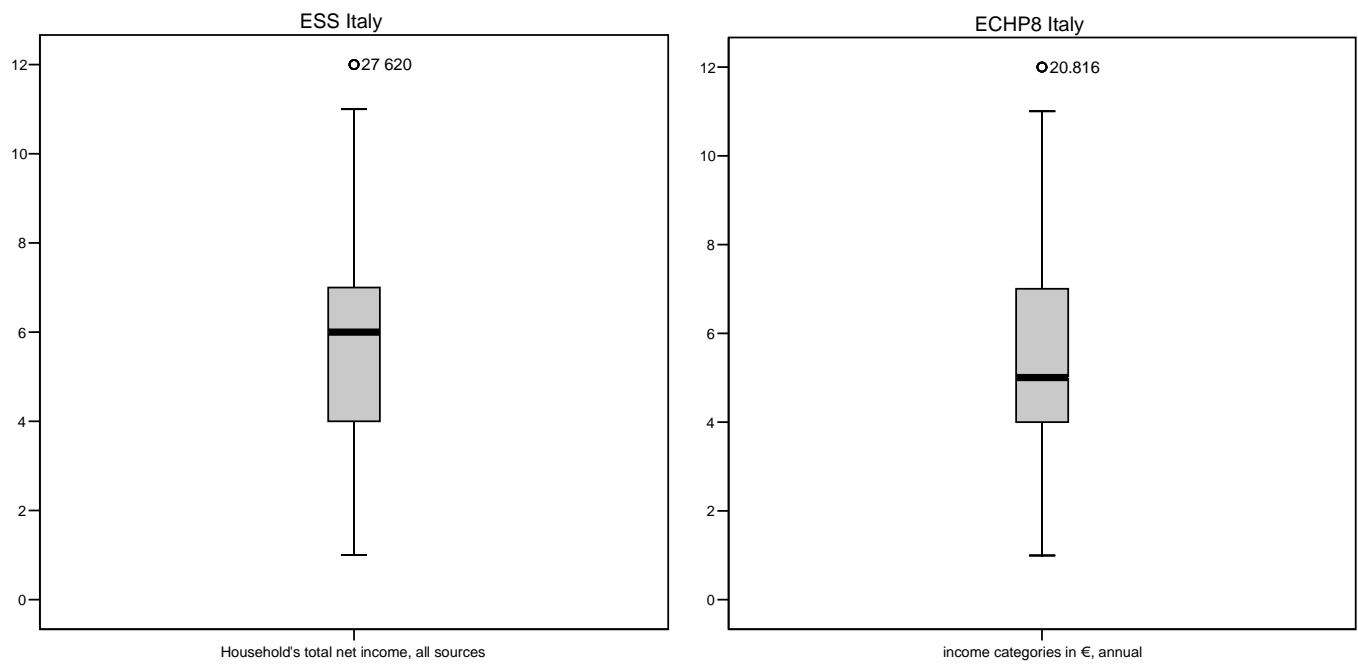

Source: ESS 2002 version Feb. 2004, ECHP UDB version April 2004 own calculations.

Figure 5: Box plot of income categories in Italy.

\section{Luxembourg}

In Luxembourg, lower categories of the income variable are not present in the wave 8 of ECHP. Only $0.2 \%$ of the households report an amount up to $6,000 €$ per year. The ESS tells us that $2.3 \%$ of the households are in the same income group.

In ESS about 3\% more households have income up to 24,000€; cumulative percent of all households from category 1 to 6 in ESS is $21 \%$ and in ECHP8 this is 
$19 \%$. In the ESS of Luxembourg the median is at the income range of 30,000$36,000 €$, the median of ECHP8 is at the category 36,000-60,000€.

$19 \%$ of the ESS respondents live in households with more than $60,000 €$. The same amount is given by $23 \%$ of the ECHP8 households.

Respondents with lower household income overestimate - and interviewees with high household income underestimate the amount of the total net household income during the ESS interview and compared to the ECHP8 outcomes.

In Luxembourg, the observed population with low income is rather small, whereas the upper end of the income distribution is common.

The upper half of the two cumulative frequencies shows remarkable differences in Luxembourg. Category 7 varies 9\% points, in category 8 the difference is $12 \%$ points and in the ninth response category both surveys diverge with $4 \%$ points.

Table 6: Cumulative frequencies of total net household income for Luxembourg.

\begin{tabular}{|r|c|r|r|}
\hline \multicolumn{2}{|c|}{ income categories } & ESS & ECHP8 \\
\hline $1:$ & $-1,800$ & 0.2 & 0.0 \\
$2:$ & $1,800-3,600$ & 1.3 & 0.1 \\
$3:$ & $3,600-6,000$ & 2.3 & 0.2 \\
$4:$ & $6,000-12,000$ & 3.5 & 1.3 \\
$5:$ & $12,000-18,000$ & 9.2 & 7.7 \\
$6:$ & $18,000-24,000$ & 21.2 & 19.4 \\
$7:$ & $24,000-30,000$ & 40.4 & 31.8 \\
$8:$ & $30,000-36,000$ & 54.6 & 42.6 \\
$9:$ & $36,000-60,000$ & 80.8 & 76.5 \\
$10:$ & $60,000-90,000$ & 94.1 & 93.9 \\
$11:$ & $90,000-120,000$ & 98.8 & 98.4 \\
$12:$ & $120,000+$ & 100.0 & 100.0 \\
\hline
\end{tabular}

Source: ESS 2002 version Feb. 2004, ECHP UDB version April 2004 own calculations.
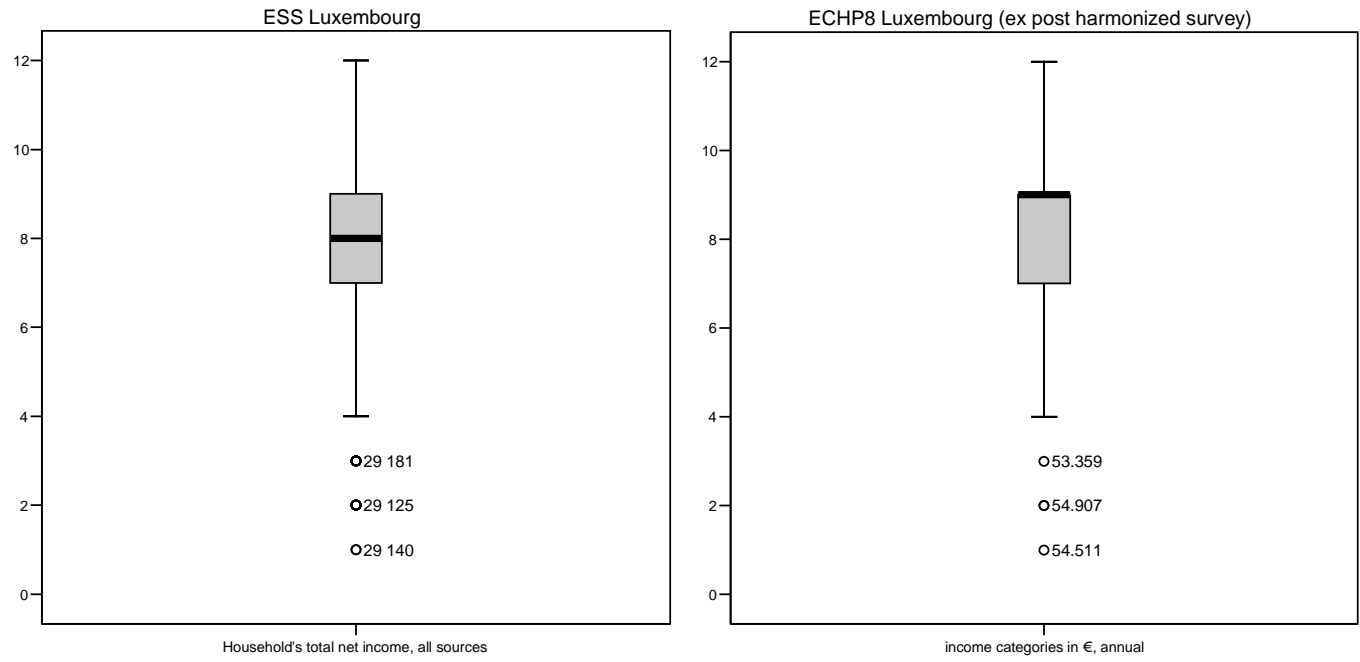

Source: ESS 2002 version Feb. 2004, ECHP UDB version April 2004 own calculations.

Figure 6: Box plot of income categories in Luxembourg. 


\section{The quality of income measurement}

The quality of answers to the income questions depends on several factors. The degree of precision of the tasks for the respondent, the operationalization of the measurement and the selection of the person eligible for the interview cause the factors having an influence on the reliability of the income answers.

From former research (Hoffmeyer-Zlotnik and Warner 1998) we assume that

1. the household definition used and the household size,

2. the selected respondent's knowledge about the financial situation of the other household members and the household as a total,

3. the main source of incomes

4. the composition of household income

5. the cognitive ability of the interviewee to remember the monetary amounts

6. will influence the response on total net household income.

\subsection{The impact of household definition and size}

The definition of household has an influence on the household size, and the number of individuals considered as household members has an impact on summing up the total household income. It is obvious, that in the participating countries the concept of "household" is defined differently.

In Germany, the household definition focuses on the common kitchen.

In United Kingdom, the daily shared meals and the common dwelling constitute a household.

In Italy, the household is defined by the common yard. One household may occupy more than one dwelling. In addition, the Italian part of ESS uses "family" during the interviews.

And finally in Luxembourg, the common living room identifies the household unit.

Different definitions of household have an implication on the household arrangements. Defined as an economic unit one dwelling consists of one or more households. Defined as dwelling unit there is one household at one dwelling. Defined as living arrangement, one household occupies one or more dwellings.

The ECHP joins together all the national definitions: “... a household is defined ... in terms of two criteria: the sharing of the same dwelling, and the common living arrangements. ... The shared arrangements may include meals taken together or a shared room ... and/or a joint budget ... and/or the use of common equipments ..." (European Commission 1996: 17). This leaves it to the member states of EU to apply their own national household settings; no harmonization took place at that stage of ECHP. 
The ESS starts at the English definition of households: "One person living alone or a group of people living at the same address (and have that address as their only or main residence), who either share at least one main meal a day or share the living accommodation (or both)." (ESS 15/07/2002: 11) This statement is made in the Project Instructions meant for the interviewers; no definition is given to the respondent during the interview. Therefore, the response person answers the question about the household income with is own underlying idea of "household". We guess that this uncertain understanding will have an impact on the number of income earners and recipients counted as household members and also on the amounts the respondent is summing up.

In the ESS questionnaire of Italy we found that not the household income is surveyed, but the Italian question asks for the "family" income: "totali nette della sua famiglia". (ESS 2002, VERSIONE ITALIANA: 19-12-02: F30) It is obvious that "family" constitutes a different membership then household definition does.

Both studies allow the respondents to uses their understanding of household implicitly.

Across nations, we get not comparable units covered by the national household concepts because of the national particularities used during the interview.

Comparing the nation across the two surveys, the same concept of household units is used during the interviews. In principal, we expect that household size is comparable across both surveys inside one country.

Table 7: Household size in ESS and ECHP wave 8 for Germany, United Kingdom, Italy and Luxembourg (column \%).

\begin{tabular}{|c|c|c|c|c|c|}
\hline Survey & $\begin{array}{c}\text { Household } \\
\text { size }\end{array}$ & Germany & $\begin{array}{c}\text { United } \\
\text { Kingdom }\end{array}$ & Italy & Luxembourg \\
\hline ESS & & & & & \\
\hline & 1 person & 18.9 & 30.3 & 9.9 & 12.6 \\
& 2 & 37.1 & 34.5 & 23.4 & 21.9 \\
& 3 & 19.2 & 15.5 & 25.6 & 22.3 \\
& 4 & 17.3 & 13.6 & 28.2 & 26.9 \\
& 5 & 5.1 & 4.7 & 10.4 & 10.8 \\
& 6 and more & 2.4 & 1.4 & 2.6 & 5.5 \\
& total & 100.0 & 100.0 & 100.0 & 100.0 \\
\hline ECHP8 & & & & & \\
\hline & 1 person & 23.1 & 24.6 & 17.5 & 23.4 \\
& 2 & 34.8 & 34.5 & 23.7 & 31.5 \\
& 3 & 19.0 & 17.6 & 25.2 & 19.9 \\
& 4 & 16.5 & 15.7 & 23.8 & 16.4 \\
& 5 & 4.9 & 5.9 & 7.3 & 6.1 \\
& 6 and more & 1.7 & 1.7 & 2.5 & 2.8 \\
& total & 100.0 & 100.0 & 100.0 & 100.0 \\
\hline
\end{tabular}

Source: ESS 2002 version Feb. 2004, ECHP UDB version April 2004 own calculations. 
The divergences between the two studies inside one country can be explained by the different response rates of the ESS based on a random sample of households. In Germany with about $20 \%$ item non response, in Italy with $47 \%$ and in Luxembourg with $37 \%$ item non response of the ESS income variable, the one person households are underrepresented. In cross sectional surveys, like ESS, it is difficult to establish contacts with one person households ${ }^{4}$.

In surveys with an official appearance by statistical offices, one person households are less complicate to contact and easier to convince for interviews. In the United Kingdom, it seems that the ESS took particular care to include interviews with person living alone in a household.

In the lower income categories we find more households with one or two members. At the upper end of the income scale larger households are more frequent. This is true in all observed countries; and is much more noticeable in ECHP8 as in ESS. In greater households the probability increases to have more then one income earner. Having in mind, that an interviewed person does not like to answer in extreme responses, we assume that the respondent living in large households underreports the amount of the household income.

Table 8: Household income categories by household size in Germany, Italy and Luxembourg (row \%).

\begin{tabular}{|c|c|c|c|c|c|c|c|c|c|c|c|c|}
\hline \multirow{3}{*}{$\begin{array}{c}\text { Income } \\
\text { Category }\end{array}$} & \multicolumn{4}{|c|}{ Germany } & \multicolumn{4}{|c|}{ Italy } & \multicolumn{4}{|c|}{ Luxembourg } \\
\hline & \multicolumn{12}{|c|}{ Household size } \\
\hline & 1 & 2 & 3,4 & $5+$ & 1 & 2 & 3,4 & $5+$ & 1 & 2 & 3,4 & $5+$ \\
\hline \multicolumn{13}{|l|}{ ESS } \\
\hline $1-3$ & 60.9 & 24.1 & 8.0 & 7.0 & 23.2 & 37.5 & 30.4 & 8.9 & 27.3 & 22.7 & 36.4 & 13.6 \\
\hline 4 & 55.7 & 26.4 & 15.1 & 2.8 & 17.9 & 32.5 & 36.6 & 13.0 & 66.7 & 16.7 & 8.3 & 8.3 \\
\hline 5 & 39.8 & 36.1 & 21.2 & 2.9 & 9.8 & 27.6 & 53.7 & 8.9 & 36.4 & 16.4 & 32.7 & 14.6 \\
\hline 6 & 13.0 & 61.9 & 31.1 & 3.9 & 9.5 & 24.8 & 60.0 & 5.7 & 35.0 & 29.9 & 28.2 & 6.9 \\
\hline 7 & 8.6 & 37.6 & 43.2 & 10.6 & 5.7 & 19.5 & 64.3 & 10.3 & 18.2 & 24.6 & 44.9 & 12.3 \\
\hline 8 & 6.9 & 36.1 & 51.6 & 5.4 & 6.7 & 15.6 & 51.1 & 26.6 & 13.0 & 28.3 & 46.4 & 12.3 \\
\hline 9 & 7.2 & 38.6 & 46.4 & 7.8 & 1.4 & 10.1 & 71.0 & 17.4 & 8.3 & 18.5 & 59.4 & 13.7 \\
\hline $10-12$ & 7.8 & 35.8 & 43.0 & 13.4 & 6.9 & 3.4 & 69.0 & 20.7 & 2.1 & 21.9 & 55.1 & 20.9 \\
\hline \multicolumn{13}{|l|}{ ECHP8 } \\
\hline $1-3$ & 71.7 & 24.2 & 4.0 & 0.0 & 54.3 & 17.1 & 24.8 & 3.9 & 75.0 & 0.0 & 25.0 & 0.0 \\
\hline 4 & 72.7 & 19.8 & 7.1 & 0.4 & 37.4 & 28.7 & 28.4 & 5.5 & 89.3 & 3.6 & 7.1 & 0.0 \\
\hline 5 & 55.5 & 31.3 & 11.6 & 1.5 & 17.5 & 30.0 & 44.1 & 8.3 & 70.3 & 20.0 & 9.0 & 0.6 \\
\hline 6 & 22.9 & 48.0 & 25.1 & 4.0 & 5.2 & 29.2 & 56.1 & 9.4 & 53.7 & 30.7 & 13.7 & 1.8 \\
\hline 7 & 8.8 & 39.1 & 44.0 & 8.0 & 2.4 & 17.0 & 69.1 & 11.5 & 35.9 & 36.9 & 23.6 & 3.7 \\
\hline 8 & 4.4 & 36.4 & 51.5 & 7.8 & 1.6 & 16.9 & 68.3 & 13.2 & 25.4 & 37.5 & 29.5 & 7.6 \\
\hline 9 & 2.7 & 31.8 & 54.1 & 11.4 & 2.0 & 9.9 & 65.7 & 22.3 & 9.8 & 34.3 & 45.4 & 10.5 \\
\hline $10-12$ & 6.3 & 24.4 & 52.0 & 17.2 & 6.2 & 17.3 & 63.0 & 13.6 & 3.9 & 27.0 & 53.0 & 16.1 \\
\hline
\end{tabular}

Source: ESS 2002 version Feb. 2004, ECHP UDB version April 2004 own calculations.

\footnotetext{
${ }^{4}$ The response rates achieved in ESS are 57\% in Germany, 44\% in Italy and Luxembourg, 56\% in the United Kingdom (ESS July 2004: 46).
} 
The ESS illustrates the following situation:

- In Germany, high incomes are received by larger households, lower income categories are more frequent in smaller households. This is true in both surveys but more pronounced in ECHP8. The two person households are distributes over the middle income categories and dominates the category with 18,000-24,000€. The income distributions by household size differ slightly across ESS and ECHP.

- In Italy, large households dominate the income groups from the forth category $(6,000-12,000 €)$ upward using ESS and using ECHP8 from category 5 (12,000-18,000€) upward. The importance of large households decreases slightly at the top income groups of ECHP8. Both surveys report the same trends and show small differences in points.

- In Luxembourg, we see the largest divergence between ECHP8 and ESS. Looking at the ECHP8 large households are seldom in the lower income categories until the category 5 with 12,000-18,000€. The ESS has large households at the lower income groups. Also in Luxembourg, the total net household income increases with the household size. But this becomes obvious in ECHP8 from category 11 (90,000-120,000€) upwards and already from category 7 (24,000-30,000€) upwards in ESS.

The overall picture from ECHP8 shows a relation between household size and household income. At the lower income categories we find nearly no large households in Luxembourg and Germany. Analyzing the low income categories, the ESS shows an image not as comprehensible as the ECHP8.

Both data show remarkable divergence of about 7 row $\%$ up to 14 row $\%$. So far we conclude that the household income measurement of ESS is not reliable for research.

\subsection{The impact of the respondent's family relation to the main income earner}

The ESS sample design selects randomly one household member as interview partner. A responding person can have a close family relationship to the main income earner. These are the partners of the main bread winner and him or herself. The other cases like the children and/or the parents and/or other relatives we interpret as interviewees, having a distant relation to the main income earner.

During the interview, we expect that answers form a close respondent are more reliable than information obtained from a person distant to the main income earner of the household.

Young (15-24 years old) respondents are distant household members in Germany and Luxembourg. In Italy the high proportion of not close household 
members also includes the age group 25 to 34 years old respondents. In United Kingdom the largest proportion of distant respondents are in the eldest age class.

Table 9: Age of the interviewee by respondent's relation to the main income earner in Germany, United Kingdom, Italy and Luxembourg (column \%) in the ESS.

\begin{tabular}{|c|cc|cc|cc|c|c|}
\hline \multirow{2}{*}{$\begin{array}{c}\text { age } \\
\text { groups }\end{array}$} & \multicolumn{9}{|c|}{ Germany } & \multicolumn{6}{c|}{ United Kingdom } & \multicolumn{2}{c|}{ Italy } & \multicolumn{2}{c|}{ Luxembourg } \\
\cline { 2 - 9 } & close* & distant* & close & distant & close & distant & close & distant \\
\hline $15-24$ & 2.6 & 34.3 & 2.1 & 18.5 & 1.5 & 29.3 & 4.2 & 48.5 \\
$25-34$ & 12.2 & 12.8 & 17.5 & 14.7 & 11.0 & 30.5 & 16.2 & 14.7 \\
$35-49$ & 36.8 & 17.7 & 32.8 & 17.4 & 35.8 & 15.0 & 35.8 & 10.6 \\
$50-64$ & 30.2 & 12.7 & 28.8 & 15.8 & 32.5 & 9.1 & 26.7 & 11.3 \\
$65-69$ & 8.5 & 5.1 & 6.6 & 6.8 & 6.5 & 3.4 & 8.3 & 4.1 \\
$70+$ & 9.7 & 17.7 & 12.1 & 26.9 & 12.6 & 12.6 & 8.8 & 10.8 \\
total & 100.0 & 100.0 & 100.0 & 100.0 & 100.0 & 100.0 & 100.0 & 100.0 \\
\hline Valid n & 1,962 & 936 & 1,236 & 811 & 799 & 406 & 920 & 584 \\
\hline
\end{tabular}

$*$ close $=$ the main income earner and the partner, distant $=$ all other relations

Source: ESS 2002 version Feb. 2004, own calculations.

Table 10: Household income categories by respondent's relation to the main income earner in Germany, United Kingdom, Italy and Luxembourg (cumulative \%) in the ESS.

\begin{tabular}{|c|cc|cc|cc|c|c|}
\hline & \multicolumn{2}{|c|}{ Germany } & \multicolumn{2}{c|}{ United Kingdom } & \multicolumn{2}{c|}{ Italy } & \multicolumn{2}{c|}{ Luxembourg } \\
\hline \multirow{2}{*}{$\begin{array}{c}\text { income } \\
\text { category }\end{array}$} & \multicolumn{9}{|c|}{ relation to main income earner } \\
\cline { 2 - 8 } & close* & distant* & close & distant & close & distant & close & distant \\
\hline $1-3$ & 1.6 & 8.8 & 3.2 & 10.4 & 7.4 & 12.0 & 1.7 & 3.4 \\
4 & 6.3 & 28.0 & 13.5 & 36.1 & 24.9 & 35.4 & 2.2 & 6.2 \\
5 & 19.0 & 53.2 & 24.9 & 50.6 & 44.3 & 54.7 & 5.7 & 16.1 \\
6 & 39.8 & 65.8 & 36.9 & 60.7 & 62.7 & 66.7 & 14.8 & 34.2 \\
7 & 59.4 & 76.6 & 47.1 & 68.2 & 77.8 & 77.1 & 34.2 & 53.1 \\
8 & 73.2 & 83.9 & 57.1 & 76.6 & 84.7 & 84.4 & 48.6 & 66.8 \\
9 & 91.2 & 95.1 & 81.0 & 89.9 & 95.5 & 95.3 & 77.4 & 87.6 \\
$10-12$ & 100.0 & 100.0 & 100.0 & 100.0 & 100.0 & 100.0 & 100.0 & 100.0 \\
\hline valid $\mathrm{n}$ & 1,640 & 696 & 1,092 & 692 & 445 & 192 & 650 & 322 \\
\hline
\end{tabular}

$*$ close $=$ the main income earner and the partner, distant $=$ all other relations

Source: ESS 2002 version Feb. 2004, own calculations.

The Table 10 shows that distant respondents answer the income questions by ticking one or two income categories lower than the main income earner or his/her partner. Interview partners not living in the center of the household economic activity underestimate the amount of the total net household income during the survey.

By increasing distance to the main income earner, the answers underestimate the total net household income, because the state of information about the financial situation of the household decreases. 


\subsection{The impact of the main source of income}

Other sources of inaccuracies measuring the financial situation of households are the main sources of income. A respondent living in a household with the income mainly from work is in general informed about the periodical and regular amount of the wage and salary received by the household members. The same is true for pensions as a main source. Unemployment benefits, social benefits or grants, income from investments, savings or property and income from other sources are additional elements, which the respondent has to add-up to the total net household income.

An increasing number of income sources will increase the complexity of adding the household income. Particular difficulties to answer the income questions we expect from respondents living in households with self employment income as the main source.

Table 11: Main source of household income by country.

\begin{tabular}{|r|r|r|r|r|}
\hline main source & Germany & $\begin{array}{r}\text { United } \\
\text { Kingdom }\end{array}$ & Italy & $\begin{array}{r}\text { Luxem- } \\
\text { bourg }\end{array}$ \\
\hline ESS & & & & \\
\hline $\begin{array}{r}\text { Wages and Salaries } \\
\text { Income from self-employment or } \\
\text { farming }\end{array}$ & 58.1 & 57.5 & 57.2 & 63.7 \\
$\begin{array}{r}\text { Pensions } \\
\text { Unemployment and redundancy } \\
\text { benefit }\end{array}$ & 26.4 & 4.3 & 16.8 & 6.8 \\
Any other social & 26.5 & 23.5 & 26.0 \\
Ang other social benefits or grants & & 1.7 & 0.9 & 0.9 \\
etc. & 2.0 & 8.1 & 0.6 & 1.3 \\
Income from investments, savings, & 0.6 & 1.0 & 0.2 & 0.1 \\
Income from other sources & 1.8 & 1.1 & 0.8 & 1.1 \\
\hline valid n & 2,893 & 2,029 & 1,123 & 1,510 \\
\hline ECHP8 & & & & \\
\hline Wages and Salaries & 61.6 & 58.6 & 49.5 & 65.0 \\
Income from self-employment or & 5.4 & 5.7 & 15.2 & 3.0 \\
farming & & & & \\
Pensions & 23.9 & 23.2 & 30.2 & 24.8 \\
benefit & 3.0 & 0.3 & 1.0 & 0.2 \\
Unemployment and redundancy & & & & \\
Any other social benefits or grants & 4.2 & 9.8 & 2.0 & 5.9 \\
Private income & 1.9 & 2.4 & 2.0 & 1.2 \\
\hline valid n & 5,559 & 4,779 & 5,525 & 2,428 \\
\hline
\end{tabular}

Source: ESS 2002 version Feb. 2004, ECHP UDB version April 2004 own calculations.

Comparing the information of ESS and ECHP8 on the main income sources of households, both studies report the same patterns.

In Germany, United Kingdom, Italy and Luxembourg, the most frequent monetary resource is income from dependent work, followed by pensions and 
retirement benefits. Both categories cover $80 \%$ to $90 \%$ of all main income sources of the household.

In Italy, the ESS surveyed $23.5 \%$ households with old age pensions and the ECHP8 reports that $30.2 \%$ of the Italian households have pensions as the main income source.

In Germany we also see a remarkable proportion of household living from unemployment benefits.

In United Kingdom social transfers are often given as main income source (9.8\% of the ECHP8 households and $8.1 \%$ of the ESS households).

Table 12: Income categories and main source of income by country.

\begin{tabular}{|c|c|c|c|c|c|c|c|c|c|}
\hline & \multicolumn{3}{|c|}{ Germany } & \multicolumn{3}{|c|}{ Italy } & \multicolumn{3}{|c|}{ Luxembourg } \\
\hline $\begin{array}{l}\text { Income } \\
\text { category }\end{array}$ & $\begin{array}{l}\text { wage, } \\
\text { salary }\end{array}$ & $\begin{array}{l}\text { self- } \\
\text { employ } \\
\text { ment }\end{array}$ & $\begin{array}{l}\text { pen- } \\
\text { sion }\end{array}$ & $\begin{array}{l}\text { wage, } \\
\text { salary }\end{array}$ & $\begin{array}{c}\text { self- } \\
\text { employ } \\
\text { ment }\end{array}$ & $\begin{array}{l}\text { pen- } \\
\text { sion }\end{array}$ & $\begin{array}{l}\text { wage, } \\
\text { salary }\end{array}$ & $\begin{array}{c}\text { self- } \\
\text { employ } \\
\text { ment }\end{array}$ & $\begin{array}{l}\text { pen- } \\
\text { sion }\end{array}$ \\
\hline \multicolumn{10}{|l|}{ ESS } \\
\hline $1-3$ & 1.5 & 3.6 & 2.8 & 6.9 & 4.0 & 13.0 & 1.3 & 2.2 & 3.3 \\
\hline 4 & 3.9 & 3.6 & 13.6 & 16.4 & 12.0 & 29.9 & 0.2 & 0.0 & 0.7 \\
\hline 5 & 11.7 & 8.6 & 24.5 & 18.6 & 14.0 & 24.7 & 4.2 & 6.5 & 7.8 \\
\hline 6 & 17.8 & 12.2 & 25.2 & 18.6 & 17.0 & 12.3 & 10.2 & 8.7 & 18.3 \\
\hline 7 & 20.8 & 10.1 & 14.8 & 15.0 & 15.0 & 11.0 & 16.4 & 15.2 & 25.0 \\
\hline 8 & 15.5 & 12.2 & 6.7 & 8.2 & 7.0 & 5.2 & 12.0 & 21.7 & 18.3 \\
\hline 9 & 19.6 & 29.5 & 9.4 & 12.3 & 20.0 & 1.9 & 30.6 & 26.1 & 19.0 \\
\hline $10-12$ & 9.3 & 20.1 & 3.0 & 4.1 & 11.0 & 1.9 & 25.0 & 19.6 & 8.2 \\
\hline \multicolumn{10}{|l|}{ ECHP8 } \\
\hline $1-3$ & 0.7 & 0.0 & 1.7 & 2.1 & 5.8 & 11.3 & 0.2 & 0.0 & 0.0 \\
\hline 4 & 3.6 & 3.0 & 17.5 & 11.2 & 16.9 & 36.3 & 0.8 & 0.0 & 1.7 \\
\hline 5 & 9.9 & 5.3 & 27.0 & 24.8 & 17.8 & 24.2 & 4.1 & 4.2 & 9.8 \\
\hline 6 & 14.4 & 8.6 & 23.1 & 19.1 & 19.3 & 13.4 & 7.4 & 5.6 & 21.8 \\
\hline 7 & 21.7 & 16.5 & 14.3 & 17.9 & 15.0 & 6.9 & 9.2 & 4.2 & 20.6 \\
\hline 8 & 18.1 & 15.8 & 7.4 & 10.6 & 8.3 & 3.8 & 10.5 & 5.6 & 13.0 \\
\hline 9 & 27.7 & 33.0 & 7.6 & 12.7 & 13.4 & 3.8 & 38.1 & 23.6 & 27.0 \\
\hline $10-12$ & 3.8 & 16.8 & 1.5 & 1.6 & 3.5 & 0.2 & 29.7 & 56.9 & 6.2 \\
\hline
\end{tabular}

Source: ESS 2002 version Feb. 2004, ECHP UDB version April 2004 own calculations.

In Luxembourg, the respondent from a household with self-employment income as main source underreports the income amounts in ESS compared to ECHP8.

In Germany and Italy, the highest income category of self-employed is overestimated during the interviews of ESS.

Respondents living in households with wages and salaries and pensions as main income source show in both surveys the similar answering behavior. 
Comparing social transfers in ESS and ECHP8, only very few cases are observed in Luxembourg and Italy who answered that social benefits are the main source of the household's income.

In the United Kingdom we can compare the two surveys, the income from social benefits is notable underreported of the income amounts in ESS. In ESS, about $2 / 3$ of the respondents with social transfers ticked the lowest income categories; in ECHP8 $27.6 \%$ of the households with social benefits have less than $12,000 €$ annual total net income from this source.

In Germany, the amounts of unemployment benefits are underreported in ESS compared with the categorized totals from ECHP8.

Table 13: Income categories and main source of income by country.

\begin{tabular}{|c|c|c|c|c|c|}
\hline & \multicolumn{2}{|r|}{ Germany } & \multirow{2}{*}{$\begin{array}{c}\text { Italy } \\
\text { social } \\
\text { benefit }\end{array}$} & \multirow{2}{*}{$\begin{array}{c}\text { United } \\
\text { Kingdom } \\
\text { social } \\
\text { benefit }\end{array}$} & \multirow{2}{*}{$\begin{array}{c}\text { Luxembourg } \\
\text { social } \\
\text { benefit }\end{array}$} \\
\hline $\begin{array}{l}\text { Income } \\
\text { categories }\end{array}$ & $\begin{array}{l}\text { social } \\
\text { benefit }\end{array}$ & $\begin{array}{c}\text { Unemployment } \\
\text { benefit }\end{array}$ & & & \\
\hline \multicolumn{6}{|l|}{ ESS } \\
\hline $1-3$ & 24.0 & 18.7 & 100.0 & 18.3 & 23.1 \\
\hline 4 & 48.0 & 29.2 & 0.0 & 48.4 & 38.5 \\
\hline 5 & 16.0 & 31.0 & 0.0 & 21.6 & 0.0 \\
\hline 6 & 2.0 & 10.6 & 0.0 & 9.2 & 0.0 \\
\hline 7 & 0.0 & 2.7 & 0.0 & 2.0 & 0.0 \\
\hline 8 & 2.0 & 5.3 & 0.0 & 0.0 & 23.1 \\
\hline 9 & 6.0 & 0.9 & 0.0 & 0.7 & 7.7 \\
\hline $10-12$ & 2.0 & 1.8 & 0.0 & 0.0 & 7.7 \\
\hline valid $n$ & 50 & 113 & 2 & 153 & 13 \\
\hline \multicolumn{6}{|l|}{ ECHP8 } \\
\hline $1-3$ & 11.7 & 5.4 & 29,7 & 7.7 & 1.4 \\
\hline 4 & 28.3 & 37.1 & 36.0 & 19.9 & 2.8 \\
\hline 5 & 23.6 & 28.1 & 16.2 & 27.8 & 19.4 \\
\hline 6 & 15.0 & 15.0 & 6.3 & 22.4 & 18.8 \\
\hline 7 & 9.4 & 7.8 & 5.4 & 11.1 & 18.1 \\
\hline 8 & 6.4 & 6.4 & 3.6 & 5.8 & 9.0 \\
\hline 9 & 5.6 & 5.6 & 2.7 & 4.1 & 26.4 \\
\hline $10-12$ & 0.0 & 0.0 & 0.0 & 1.3 & 4.2 \\
\hline valid $n$ & 233 & 167 & 111 & 468 & 144 \\
\hline
\end{tabular}

Source: ESS 2002 version Feb. 2004, ECHP UDB version April 2004 own calculations. 


\subsection{The impact of income composition}

The ECHP interviews ask for 21 possible income sources. Every member of a household aged 15 and older is requested to remember these monetary items and give the amount received.

Most of the persons have to give an account for five or six different income sources.

In Italy $24 \%$ of the ECHP individuals have no income from any source. The highest proportion of people having income receive the money from six various sources. $63 \%$ of the Italians have three up to six different income sources.

Table 14: Number of income sources by proportion of individuals in ECHP wave 8.

\begin{tabular}{|r|r|r|r|r|}
\hline & Germany & $\begin{array}{c}\text { United } \\
\text { Kingdom }\end{array}$ & Italy & $\begin{array}{c}\text { Luxem- } \\
\text { bourg }\end{array}$ \\
\hline no income source & 6.6 & 1.4 & 24.6 & 17.3 \\
1 and 2 income source & 0.8 & 0.6 & 1.1 & 0.0 \\
3 & 5.5 & 5.3 & 11.5 & 7.0 \\
4 & 7.6 & 5.9 & 17.7 & 10.5 \\
5 & 5.3 & 8.8 & 6.3 & 26.1 \\
6 & 19.8 & 25.6 & 27.1 & 8.6 \\
7 & 18.2 & 12.4 & 3.3 & 19.7 \\
8 & 9.5 & 18.2 & 6.1 & 4.1 \\
9 & 9.4 & 11.1 & 1.7 & 4.6 \\
10 & 7.0 & 5.8 & 0.4 & 1.9 \\
11 & 8.6 & 3.6 & 0.2 & 0.3 \\
12 & 1.5 & 1.0 & 0.0 & 0.0 \\
13 and more income sources & 0.2 & 0.2 & 0.0 & 0.0 \\
\hline valid $\mathrm{n}$ & 10,624 & 8,521 & 13,392 & 4,916 \\
\hline
\end{tabular}

Source: ECHP UDB version April 2004, own calculations.

In Germany between six and eleven income sources are answered. More then $72 \%$ of the individuals have to report on such complex income composition.

In the United Kingdom most of the interviewee has to remember five to nine sources of revenues. 9\% of the ECHP individuals have more then nine income sources.

In Luxembourg, the most people have to sum up five different income components, and $17 \%$ have no income sources to mention. Only $11 \%$ of the Luxembourg ECHP individuals have more than seven different incomes.

The Table 15 about income categories by number of income sources shows: As less income sources are reported, as lower is the household income. This is true for the data of ECHP8. During the interview, the respondent is asked income component by component. Therefore it is less probable that the interviewee can 
forget the single income item. All items are remembered during the interaction of the interview.

Table 15: Income categories by number of income sources (column \%) of ECHP8.

\begin{tabular}{|c|c|c|c|c|c|c|c|c|c|c|c|c|}
\hline & \multicolumn{3}{|c|}{ Germany } & \multicolumn{3}{|c|}{ United Kingdom } & \multicolumn{3}{|c|}{ Italy } & \multicolumn{3}{|c|}{ Luxembourg } \\
\hline \multirow{2}{*}{$\begin{array}{l}\text { in- } \\
\text { come } \\
\text { cate- } \\
\text { gory }\end{array}$} & \multicolumn{12}{|c|}{ number of income sources } \\
\hline & $4-6$ & $7-8$ & $9-13$ & $4-6$ & $7-8$ & $9-13$ & $4-6$ & $7-8$ & $9-13$ & $4-6$ & $7-8$ & $9-13$ \\
\hline 4 & 7.7 & 5.9 & 3.7 & 10.9 & 5.8 & 2.9 & 16.4 & 7.8 & 6.6 & 1.0 & 0.3 & 0.0 \\
\hline 5 & 12.2 & 12.0 & 8.7 & 13.3 & 9.0 & 5.8 & 19.9 & 15.8 & 13.2 & 5.5 & 2.2 & 1.2 \\
\hline 6 & 18.9 & 12.9 & 12.1 & 13.9 & 10.4 & 8.9 & 18.0 & 17.1 & 16.9 & 10.1 & 5.7 & 3.9 \\
\hline 7 & 19.3 & 17.3 & 21.3 & 11.8 & 12.1 & 11.2 & 16.6 & 18.6 & 16.3 & 10.9 & 9.2 & 6.0 \\
\hline 8 & 14.0 & 16.5 & 18.9 & 11.4 & 12.2 & 12.4 & 9.9 & 15.7 & 10.7 & 9.8 & 10.8 & 5.7 \\
\hline 9 & 21.5 & 29.4 & 29.8 & 26.0 & 35.1 & 38.7 & 13.6 & 20.4 & 28.5 & 35.4 & 38.8 & 39.3 \\
\hline 10 & 3.8 & 4.5 & 4.3 & 8.4 & 12.0 & 15.8 & 1.3 & 2.5 & 4.7 & 20.5 & 23.6 & 32.4 \\
\hline 11 & 0.5 & 0.5 & 0.4 & 1.5 & 1.9 & 2.6 & 0.2 & 0.4 & 1.6 & 5.3 & 6.3 & 8.7 \\
\hline 12 & 0.2 & 0.3 & 0.2 & 0.8 & 0.8 & 1.4 & 0.0 & 0.0 & 0.6 & 1.4 & 3.1 & 2.7 \\
\hline $\begin{array}{r}\text { valid } \\
n\end{array}$ & 3,477 & 2,937 & 2,836 & 3,436 & 2,610 & 1,852 & 6,831 & 1,262 & 319 & 2,220 & 1,167 & 333 \\
\hline
\end{tabular}

Source: ECHP UDB version April 2004, own calculations.

In Germany, the middle and higher income have little differences reporting the number of income sources.

In the United Kingdom, lower income categories and income groups at the upper end of the income distribution show a relation between the income amount and the number of income sources reported. Having more income sources in the United Kingdom, compared to the other three countries, we assume that also more household members receive income from different sources.

In Italy, bigger households receive higher incomes from a larger number of income sources. More household members with income from work contribute to the total net household income in Italy.

Also in Luxembourg, the high income depends on the number of income sources and the number of individuals getting income from different sources, in particular income from work.

\subsection{The impact of remembering income}

The detailed fieldwork instrument of ECHP8 shows the complexity of the measurement "total net household income". In average six and sometimes 13 and more income components are reality for the respondent.

The straightforward questions of ESS recall only the main income source of the respondent's household. These are income from work, a periodical source and a constant amount of money, the interviewed person can answer the ESS query. 
The same is true for payments replacing the income from work, like pensions, unemployment benefits and alimonies; these are easily remembered by the interviewees.

For all other types of income the questionnaire has to ask separate questions to remind the interview partner about this monetary item.

At the same time, the household member selected at random for the interview must have the knowledge about the variety of the household income components. The ESS surveyed a randomly sampled member of the household as a reference person for the household. This can be the main income earner or his/her partner, including housekeeping partners, with a good knowledge on the income situation or other household members having weak information about all monetary items received by all household members.

The following figures illustrate the proportion of well informed respondents having a good knowledge minus the proportion of less informed interviewees by household income category. A negative bar shows that more interview partners less informed than well informed have chosen that income brackets.

The less informed reference persons dominate in the lower income categories. In Germany, the impact on the fourth and fifth income group is observable. In United Kingdom, the less informed persons of contact have an influence only on category $5(12,000 €$ to $18,000 €)$; up to the income group $8(30,000 €$ to $36,000 €)$, there is a balance between good informed answers and reference persons with a weak knowledge on the total net household income.

For Italy, we assume that in the categories $3(3,600 €$ to $6,000 €)$ and $4(6,000 €$ to $12,000 €)$ the less informed people underestimate the amount of the household income, and there is a slight effect on the top two income groups.

In Luxembourg, the influence of respondents with less knowledge on the total household income is visible in the lower part of the income distribution.

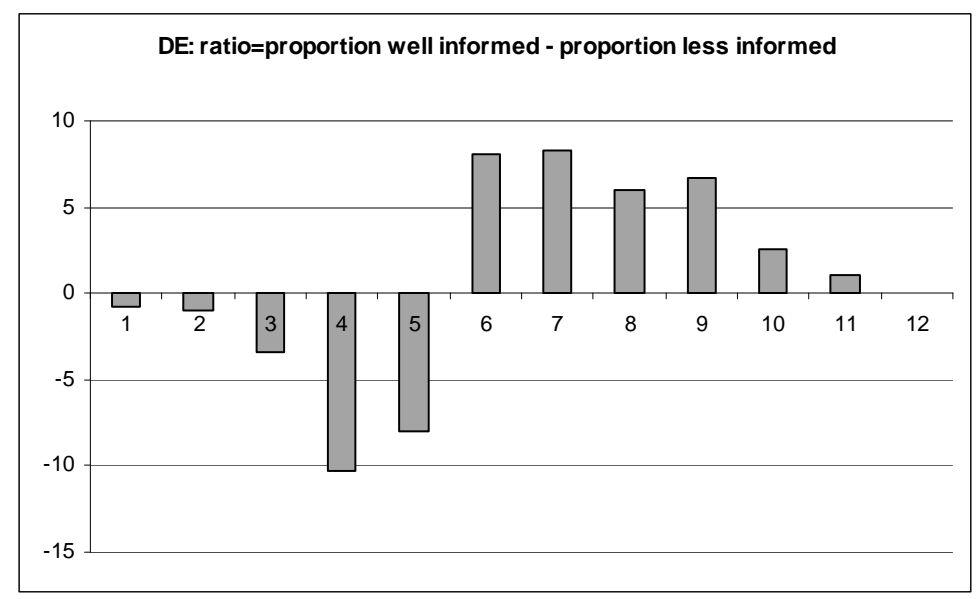

Figure 7: Well informed vs. less informed interviewees by income categories in Germany. 


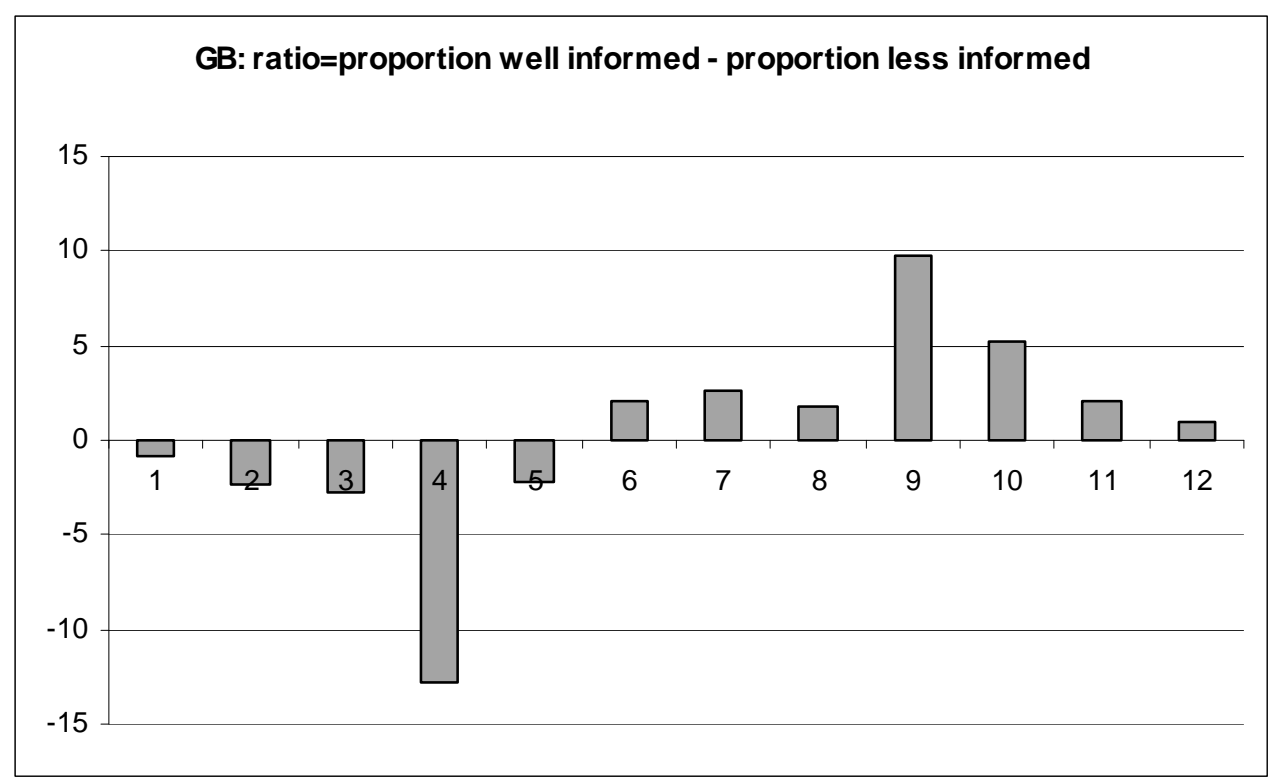

Figure 8: Well informed vs. less informed interviewees by income categories in United Kingdom.

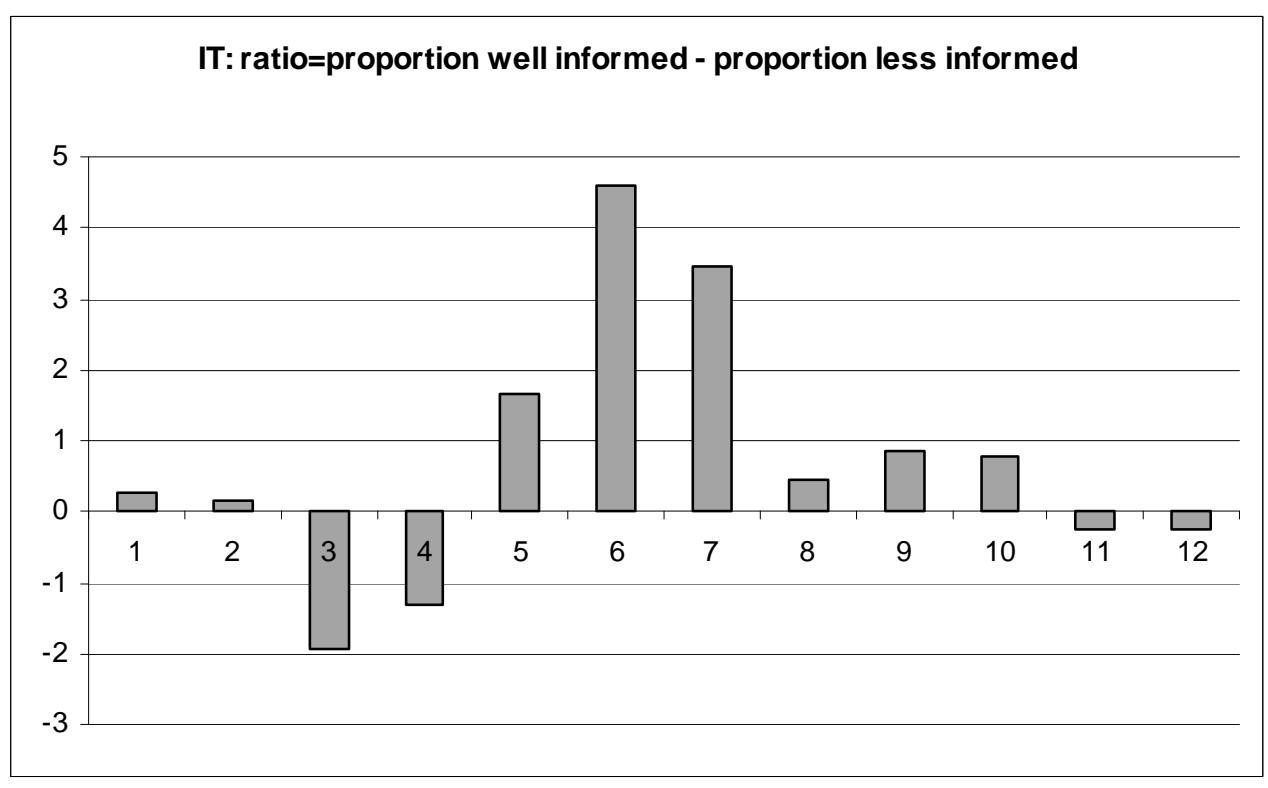

Figure 9: Well informed vs. less informed interviewees by income categories in Italy. 


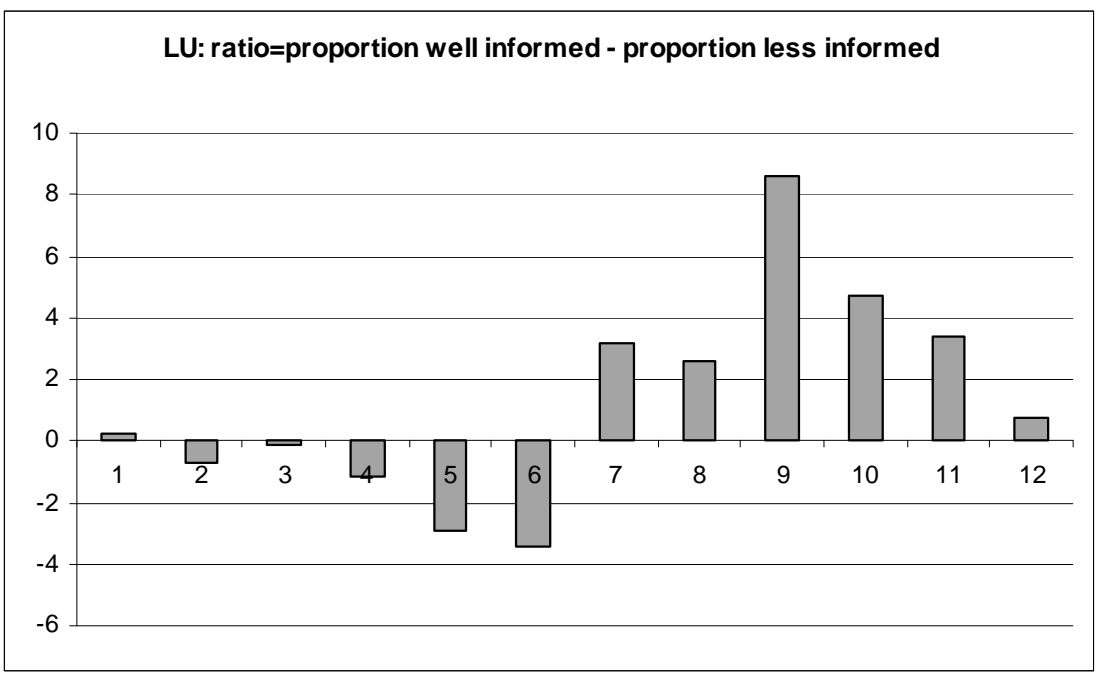

Figure 10: Well informed vs. less informed interviewees by income categories in Luxembourg.

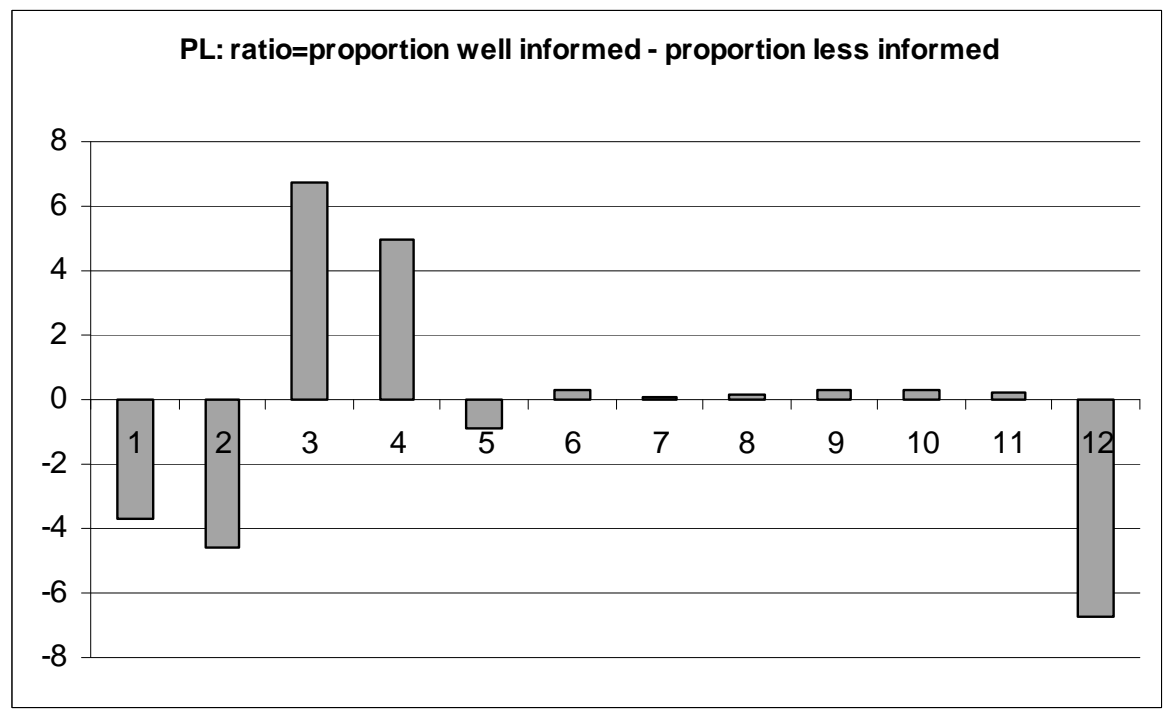

Figure 11: Well informed vs. less informed interviewees by income categories in Poland.

For the other countries participating in ESS, we observe that up to the income category $8(30,000 €$ to $36,000 €)$ in countries with an higher average of total net household income the proportion of less informed respondents are larger than the proportion of well informed; and we again assume that the sum of the total net 
household income is underestimated (e.g. Switzerland, Sweden and Finland). The impact of less informed reference persons in countries with a lower average of income is seen in the categories 1 (less than 1,800€) and $2(1,800 €$ to $3,600 €)$; in Portugal, Hungary and Poland these income ranges are dominated by the less informed answering person.

A particular situation is empirically visible in Poland. From category 5 $(12,000 €$ to $18,000 €)$ to category $11(90,000 €$ to $120,000 €)$ we have as much informed as not informed responses and the twelfth group is mainly built by respondents with less knowledge of the income.

\section{The quality of the survey instrument}

We have discussed so far the household structure, the cognitive abilities of the respondent and the income composition.

We focus now on two questions:

1. How to improve the fieldwork instrument?

2. Which additional information is necessary to evaluate the quality

of the responses?

Improving the fieldwork instrument depends on one hand the evaluation of the question wording and on the other hand the evaluation of the universal validity of the answer categories. In consequence we formulate new questions to ask for the total net household income in social surveys.

\subsection{Categorizing income for comparative social research}

We are looking for "optimal" answer categories for the interviews asking the income question in various national contexts.

By cutting the income variable of ECHP8 into 5\% groups of the population and sorting the ESS categories into the ECHP8 distribution, we illustrate the need to adjust the income brackets to national financial circumstances and the national income distributions.

The ESS category $36,000 €$ to $60,000 €$ covers the $9^{\text {th }}$ to the $15^{\text {th }} 5 \%$ percentiles of the income distribution in Luxembourg. In Germany, the same income group covers the $15^{\text {th }}$ to $19^{\text {th }} 5 \%$ percentiles. In Portugal, the richest $5 \%$ of the population have a total net household income of $36,000 €$ to $60,000 €$. Also, the poorest $5 \%$ of the Luxembourg people have a higher household income than $55 \%$ of the Portuguese population and $50 \%$ of the Italians.

Respondents from all countries need about six ESS categories to answer the income question. But the nationally used answer categories differ across the countries. 
Table 16: 5\% percentiles of the total household net income in ECHP8 for selected countries.

\begin{tabular}{|c|c|c|c|c|c|c|c|}
\hline \multicolumn{2}{|c|}{$\begin{array}{c}\text { income } \\
\text { percentiles } \\
\text { no. } / \%\end{array}$} & \multirow{2}{*}{$\begin{array}{r}\text { Germany } \\
8,658\end{array}$} & \multirow{2}{*}{$\begin{array}{c}\begin{array}{c}\text { United } \\
\text { Kingdom }\end{array} \\
7,781\end{array}$} & \multirow{2}{*}{$\begin{array}{l}\text { Italy } \\
5,163\end{array}$} & \multirow{2}{*}{$\begin{array}{l}\begin{array}{l}\text { Luxem- } \\
\text { bourg }\end{array} \\
16,039\end{array}$} & \multirow{2}{*}{$\begin{array}{c}\text { Portuga } \\
1\end{array}$} & \multirow{2}{*}{$\begin{array}{r}\text { Finland } \\
6,203\end{array}$} \\
\hline 1 & $5 \%$ & & & & & & \\
\hline 2 & $10 \%$ & 11,327 & 10,632 & 7,218 & 19,503 & 3,328 & 8,309 \\
\hline 3 & $15 \%$ & 13,752 & 12,535 & 8,728 & 22,310 & 4,141 & 10,258 \\
\hline 4 & $20 \%$ & 15,769 & 14,961 & 10,071 & 24,374 & 4,920 & 12,504 \\
\hline 5 & $25 \%$ & 17,507 & 17,271 & 11,310 & 27,088 & 5,658 & 14,504 \\
\hline 6 & $30 \%$ & 19,537 & 19,612 & 12,395 & 29,509 & 6,453 & 16,176 \\
\hline 7 & $35 \%$ & 21,249 & 21,829 & 13,634 & 32,308 & 7,388 & 17,844 \\
\hline 8 & $40 \%$ & 23,129 & 24,316 & 14,901 & 34,620 & 8,394 & 19,654 \\
\hline 9 & $45 \%$ & 24,745 & 26,774 & 16,205 & 37,067 & 9,389 & 21,432 \\
\hline 10 & $50 \%$ & 26,541 & 29,400 & 17,849 & 39,530 & 10,385 & 23,572 \\
\hline 11 & $55 \%$ & 28,032 & 31,865 & 19,419 & 42,142 & 11,333 & 25,765 \\
\hline 12 & $60 \%$ & 29,780 & 34,816 & 21,156 & 45,378 & 12,381 & 28,056 \\
\hline 13 & $65 \%$ & 31,767 & 37,552 & 22,987 & 49,571 & 13,553 & 30,226 \\
\hline 14 & $70 \%$ & 33,816 & 40,861 & 25,100 & 53,859 & 14,816 & 32,438 \\
\hline 15 & $75 \%$ & 36,108 & 44,335 & 27,165 & 59,059 & 16,398 & 34,883 \\
\hline 16 & $80 \%$ & 39,097 & 48,239 & 29,541 & 63,653 & 18,516 & 37,697 \\
\hline 17 & $85 \%$ & 42,763 & 53,432 & 32,592 & 70,746 & 20,950 & 40,990 \\
\hline 18 & $90 \%$ & 47,796 & 61,142 & 37,092 & 79,787 & 24,744 & 46,582 \\
\hline 19 & $95 \%$ & 56,613 & 72,806 & 45,489 & 95,240 & 32,166 & 56,414 \\
\hline Valid & & 5,559 & 4,779 & 5,525 & 2,428 & 4,588 & 3,106 \\
\hline
\end{tabular}

Source: ECHP UDB version April 2004, own calculations.

Table 17: The distribution of the $195 \%$ percentiles from ECHP8 by the 12 income categories of ESS in selected countries.

\begin{tabular}{|r|r|r|r|r|r|r|}
\hline & $\begin{array}{c}\text { Ger- } \\
\text { many }\end{array}$ & $\begin{array}{c}\text { United } \\
\text { King- } \\
\text { dom }\end{array}$ & Italy & $\begin{array}{c}\text { Luxem- } \\
\text { bourg }\end{array}$ & Portugal & Finland \\
\hline ESS categories & \multicolumn{7}{|c|}{ No. of the ECHP8 5\% percentile } \\
\hline up to 1,800 & --- & --- & --- & --- & --- & --- \\
$1,800-3,600$ & --- & --- & --- & --- & $1-2$ & --- \\
$3,600-6,000$ & --- & -- & 1 & --- & $3-5$ & -- \\
$6,000-12,000$ & $1-2$ & $1-2$ & $2-5$ & --- & $6-11$ & $1-3$ \\
$12,000-18,000$ & $3-5$ & $3-5$ & $6-10$ & 1 & $12-15$ & $4-7$ \\
$18,000-24,000$ & $6-8$ & $6-7$ & $11-13$ & $2-3$ & $16-17$ & $8-10$ \\
$24,000-30,000$ & $9-12$ & $8-10$ & $14-16$ & $4-6$ & 18 & $11-12$ \\
$30,000-36,000$ & $13-14$ & $11-12$ & 17 & $7-8$ & 19 & $13-15$ \\
$36,000-60,000$ & $15-19$ & $13-17$ & $18-19$ & $9-15$ & --- & $16-19$ \\
$60,000-90,000$ & --- & $18-19$ & --- & $16-18$ & --- & --- \\
$90,000-120,000$ & --- & --- & --- & 19 & --- & --- \\
120,000 and more & --- & --- & --- & --- & --- & --- \\
\hline
\end{tabular}

Source: ECHP UDB version April 2004, own calculations. 
Table 18: Proposed system of income categories for selected European countries.

\begin{tabular}{|c|c|c|c|c|c|c|c|}
\hline no & $\begin{array}{l}\text { income } \\
\text { categories } \\
\text { in EURO. }\end{array}$ & $\begin{array}{l}\text { Ger- } \\
\text { many }\end{array}$ & $\begin{array}{l}\text { United } \\
\text { King- } \\
\text { dom }\end{array}$ & Italy & $\begin{array}{l}\text { Luxem- } \\
\text { bourg }\end{array}$ & Portugal & Finland \\
\hline 1.0 & $-2,500$ & & & 1.5 & & 5.8 & \\
\hline 2.1 & $2,500-5,000$ & & & 3.8 & & 16.3 & \\
\hline 2.2 & $-5,000$ & 0.9 & 1.9 & & & & 3.5 \\
\hline 3.0 & $5,000-10,000$ & 6.2 & 7.8 & & & & 10.9 \\
\hline 3.1 & $5,000-7,500$ & & & 7.3 & & 15.7 & \\
\hline 3.2 & $7,500-10,000$ & & & 9.3 & & 13.1 & \\
\hline 3.3 & $-10,000$ & & & & 0.6 & & \\
\hline 4.0 & $10,000-15,000$ & 11.1 & 12.3 & & 3.2 & & 12.3 \\
\hline 4.1 & $10,000-12,500$ & & & 11.8 & & 12.0 & \\
\hline 4.2 & $12,500-15,000$ & & & 10.3 & & 10.1 & \\
\hline 5 & $15,000-20,000$ & 13.6 & 11.7 & 16.6 & 7.1 & 11.6 & 15.0 \\
\hline 6 & $20,000-25,000$ & 15.1 & 10.3 & 12.9 & 9.9 & 7.0 & 11.9 \\
\hline 7 & $25,000-30,000$ & 15.1 & 10.1 & 10.4 & 10.9 & 3.4 & 11.4 \\
\hline 8 & $30,000-35,000$ & 12.2 & 8.7 & 6.5 & 8.9 & 1.9 & 10.6 \\
\hline 9 & $35,000-40,000$ & 8.6 & 8.3 & 3.9 & 10.0 & 1.0 & 8.5 \\
\hline 10 & $40,000-45,000$ & 5.6 & 6.3 & 1.7 & 8.9 & 0.7 & 4.8 \\
\hline 11 & $45,000-50,000$ & 4.2 & 6.0 & 1.6 & 6.3 & 0.3 & 3.5 \\
\hline 12 & $50,000-55,000$ & 2.5 & 4.1 & 0.8 & 5.5 & 0.3 & 2.2 \\
\hline 13 & $55,000-60,000$ & 1.3 & 3.0 & 0.7 & 5.2 & 0.3 & 1.4 \\
\hline 14 & $60,000+$ & & & 0.9 & & 0.5 & \\
\hline 15 & $60,000-70,000$ & 1.7 & 4.3 & & 8.1 & & 1.8 \\
\hline 16 & $70,000+$ & 2.0 & 5.3 & & & & 2.2 \\
\hline 17 & $70,000-80,000$ & & & & 5.5 & & \\
\hline 18 & $80,000-90,000$ & & & & 3.9 & & \\
\hline 19 & $90,000-100,000$ & & & & 2.5 & & \\
\hline 20 & $100,000-110,000$ & & & & 1.2 & & \\
\hline 21 & $110,000+$ & & & & 2.3 & & \\
\hline
\end{tabular}

Source: ECHP UDB version April 2004, own calculations.

We propose for Germany, United Kingdom and Finland a system of income categories starting with an annual total net household income up to 5,000€. The scale continues in $5,000 €$ steps to the amount of $60,000 €$. The top category is $70,000 €$ and more

In Luxembourg the income responses begin with the income up to $10,000 €$. At the top of the income scale Luxembourg needs $10,000 €$ brackets until $110,000 €$ is reached.

Italy and Portugal need an extension at the bottom part of the income distribution. The first group is the annual household income up to $2,500 €$, continued in 2,500€ classes until 15,000€ is reached. From here, 5,000€ groups up to the top of $60,000 €$ completes the income response categories.

The proposed income categories take into account the differences in the national income distributions. These diversities are observed and measured by income brackets of 5,000€. For countries with a larger population at the bottom 
end of the income curve, the income classes are in 2,500€. At the top end of the income inequality, our proposed income scales take into account the population size with high incomes. In a wealthy country, the scale continues in $10,000 €$ brackets. Comparing Luxembourg and Portugal illustrates the advantages. $0.5 \%$ of the population in Portugal has a total net household income of 60,000€ and more; but every fourth respondent living in a Luxembourg household reports 60,000€ and more.

\subsection{Consequences for the question wording}

In ESS the question about income starts with a list of income sources, where the respondent has to indicate the main source of the household income. Seven income types are mentioned and differently detailed across the countries.

Guided by the final recommendations of the Canberra group (2001), we propose a list of eight income titles for comparative social survey research. Each title is explained by the most common income sources. So, the respondent remembers all sources except goods and services provided as part of the employment packages and payment in kind. Non cash income is not covered by our proposed list of income sources, because these non monetary incomes have no relevance in social research.

We recommend asking for all income sources of every household member first. The interview partner gives all applicable sources. The respondent is not oriented to only one income source.

Still having in mind all sources and all persons living in the household, the interviewee is asked about the amount of the total net household income. Net we specify as the sum after deduction of national taxes and after deduction of compulsory contributions to the national social security system. So the respondent knows the income elements to sum up and the elements to subtract. The answers are coded in a national system of categories reflecting the income distribution of the country.

The third information we want to obtain is the number of persons contributing to the household's total income.

The forth question asks for the main source of the income by using again the list of sources from the first question. Only one answer is possible.

And finally, we prefer to know the relationship of the respondent to the main income earner. As illustrated, we can now evaluate the quality of the answer to the income question.

The advantage of this proposed sequence of questions is that at the beginning the interviewed person recalls all income types and all household members and later the interviewee's attention is drawn to only one main income source.

The questions formulate assignments to remember, to determine and to calculate the total net household income. The first task of the respondent is to 
trace all possible monetary resources of every household member; summing up all amounts is the second duty; the deduction of taxes and contributions is the final step.

The formulation of the income sources used in question 1 allows to compare the obtained answer to the income question, because the elements are common in all countries. The income types used during the calculation of the totals are knows to the interviewee and to the researcher analyzing the income variables in comparative perspective.

Question 3 is not only a query on the persons contributing to the income, but the researcher has the opportunity to control the plausibility of the income amount. At the same time the respondent has the chance to verify the answer to question 2 : Are all sources and all persons included in the calculation?

Question 4 allows the researcher to create a household typology.

Question 5 allows to identify the over or under estimation of the total net household income.

\section{Question 1}

Please consider the income of every member of the household and any income which may be received by the household as a whole. What are the sources of income in your household? Please tick all applicable.

\begin{tabular}{|l|}
\hline ALL INCOME SOURCES OF YOUR HOUSEHOLD \\
\hline $\begin{array}{l}\text { Employee income, } \\
\text { including bonuses (e.g. vacation or Christmas), tips, extra payments (from e.g. } \\
\text { overtime and shift work), profit sharing }\end{array}$ \\
\hline Income from self-employment or farming, also free-lance work \\
\hline $\begin{array}{l}\text { Pensions, } \\
\text { including old age and widow's pensions, retirement }\end{array}$ \\
\hline $\begin{array}{l}\text { Unemployment / redundancy benefits, } \\
\text { including benefits related to training and sickness allowances }\end{array}$ \\
\hline Rentals and Property income \\
\hline $\begin{array}{l}\text { Current public transfers received, social benefits and grants } \\
\text { including child and family allowances, universal and/or means-tested social } \\
\text { assistance and orphan's pensions, educational grants }\end{array}$ \\
\hline $\begin{array}{l}\text { Regular private transfers from persons outside your own household } \\
\text { including alimony }\end{array}$ \\
\hline $\begin{array}{l}\text { Income from other sources } \\
\text { including reimbursements from taxes and insurances, lottery winnings }\end{array}$ \\
\hline
\end{tabular}




\section{Question 2}

If you add up the income from all sources and all household members (from the target population), which letter describes your household's total net income? Net is after deduction of national taxes and after deduction of compulsory contributions to the national social security. If you don't know the exact figure, please give an estimate. Use the part of the card that you know best: weekly, monthly or annual income.

Table 19: Proposed categories for type 1, countries like Italy and Portugal.

\begin{tabular}{|l|l|l|l|l|}
\hline \multicolumn{5}{|c|}{ YOUR NET HOUSEHOLD INCOME } \\
\hline & $\begin{array}{c}\text { Approximate } \\
\text { WEEKLY }\end{array}$ & $\begin{array}{c}\text { Approximate } \\
\text { MONTHLY }\end{array}$ & \multicolumn{1}{c|}{$\begin{array}{c}\text { Approximate } \\
\text { ANNUAL }\end{array}$} & \\
\hline M & & & Less than $2,500 €$ & M \\
\hline B & & & 2,500 to under $5,000 €$ & B \\
\hline F & & & 5,000 to under $7,500 €$ & F \\
\hline G & & & 7,500 to under $10,000 €$ & G \\
\hline Q & & & 10,000 to under $12,500 €$ & Q \\
\hline N & & & 12,500 to under $15,000 €$ & N \\
\hline T & & & 15,000 to under $20,000 €$ & T \\
\hline D & & & 20,000 to under $25,000 €$ & D \\
\hline K & & 25,000 to under $30,000 €$ & K \\
\hline W & & 30,000 to under $35,000 €$ & W \\
\hline H & & 35,000 to under $40,000 €$ & H \\
\hline C & & & 40,000 to under $45,000 €$ & C \\
\hline J & & & 45,000 to under $50,000 €$ & J \\
\hline U & & & 50,000 to under $55,000 €$ & U \\
\hline I & & & 55,000 to under $60,000 €$ & I \\
\hline Z & & & $60,000 €$ and more & Z \\
\hline
\end{tabular}

Table 20: Proposed categories for type 2, countries like Germany, United Kingdom, Finland.

\begin{tabular}{|l|l|l|l|l|}
\hline \multicolumn{5}{|c|}{ YOUR NET HOUSEHOLD INCOME } \\
\hline & $\begin{array}{c}\text { Approximate } \\
\text { WEEKLY }\end{array}$ & $\begin{array}{c}\text { Approximate } \\
\text { MONTHLY }\end{array}$ & \multicolumn{1}{c|}{$\begin{array}{c}\text { Approximate } \\
\text { ANNUAL }\end{array}$} & \\
\hline $\mathrm{O}$ & & & Less than $5,000 €$ & $\mathrm{O}$ \\
\hline $\mathrm{V}$ & & & 5,000 to under $10,000 €$ & $\mathrm{~V}$ \\
\hline $\mathrm{L}$ & & & 10,000 to under $15,000 €$ & $\mathrm{~L}$ \\
\hline $\mathrm{T}$ & & & 15,000 to under $20,000 €$ & $\mathrm{~T}$ \\
\hline $\mathrm{D}$ & & & 20,000 to under $25,000 €$ & $\mathrm{D}$ \\
\hline $\mathrm{K}$ & & & 25,000 to under $30,000 €$ & $\mathrm{~K}$ \\
\hline $\mathrm{W}$ & & & 30,000 to under $35,000 €$ & $\mathrm{~W}$ \\
\hline $\mathrm{H}$ & & & 35,000 to under $40,000 €$ & $\mathrm{H}$ \\
\hline $\mathrm{C}$ & & & 40,000 to under $45,000 €$ & $\mathrm{C}$ \\
\hline $\mathrm{J}$ & & & 45,000 to under $50,000 €$ & $\mathrm{~J}$ \\
\hline $\mathrm{U}$ & & & 50,000 to under $55,000 €$ & $\mathrm{U}$ \\
\hline $\mathrm{I}$ & & & 55,000 to under $60,000 €$ & $\mathrm{I}$ \\
\hline $\mathrm{S}$ & & & 60,000 to under $70,000 €$ & $\mathrm{~S}$ \\
\hline $\mathrm{E}$ & & & $70,000 €$ and more & $\mathrm{E}$ \\
\hline
\end{tabular}


The columns "approximate weekly" and "approximate monthly" must be filled in by the corresponding rounded values so that the income classes do not change, e.g. for the category $\mathrm{O}$ weekly is "less than $100 €$ " and monthly becomes "less than $400 € "$.

Table 21: Proposed categories for type 3, countries like Luxembourg.

\begin{tabular}{|l|l|l|l|l|}
\hline \multicolumn{2}{|c|}{ YOUR NET HOUSEHOLD INCOME } \\
\hline & $\begin{array}{c}\text { Approximate } \\
\text { WEEKLY }\end{array}$ & $\begin{array}{c}\text { Approximate } \\
\text { MONTHLY }\end{array}$ & \multicolumn{1}{c|}{$\begin{array}{c}\text { Approximate } \\
\text { ANNUAL }\end{array}$} & \\
\hline $\mathrm{O}$ & & & Less than $10,000 €$ & $\mathrm{O}$ \\
\hline $\mathrm{L}$ & & & 10,000 to under $15,000 €$ & $\mathrm{~L}$ \\
\hline $\mathrm{T}$ & & & 15,000 to under $20,000 €$ & $\mathrm{~T}$ \\
\hline $\mathrm{D}$ & & & 20,000 to under $25,000 €$ & $\mathrm{D}$ \\
\hline $\mathrm{K}$ & & & 25,000 to under $30,000 €$ & $\mathrm{~K}$ \\
\hline $\mathrm{W}$ & & & 30,000 to under $35,000 €$ & $\mathrm{~W}$ \\
\hline $\mathrm{H}$ & & & 35,000 to under $40,000 €$ & $\mathrm{H}$ \\
\hline $\mathrm{C}$ & & & 40,000 to under $45,000 €$ & $\mathrm{C}$ \\
\hline $\mathrm{J}$ & & & 45,000 to under $50,000 €$ & $\mathrm{~J}$ \\
\hline $\mathrm{U}$ & & & 50,000 to under $55,000 €$ & $\mathrm{U}$ \\
\hline $\mathrm{I}$ & & & 55,000 to under $60,000 €$ & $\mathrm{I}$ \\
\hline $\mathrm{S}$ & & & 60,000 to under $70,000 €$ & $\mathrm{~S}$ \\
\hline $\mathrm{Y}$ & & & 70,000 to under $80,000 €$ & $\mathrm{Y}$ \\
\hline $\mathrm{X}$ & & & 80,000 to under $90,000 €$ & $\mathrm{X}$ \\
\hline $\mathrm{A}$ & & & 90,000 to under $100,000 €$ & $\mathrm{~A}$ \\
\hline $\mathrm{R}$ & & & 100,000 to under $110,000 €$ & $\mathrm{R}$ \\
\hline $\mathrm{P}$ & & & $110,000 €$ and more & $\mathrm{P}$ \\
\hline
\end{tabular}

\section{Question 3}

How many household members contribute to the household's total net income?

\section{Question 4}

Please consider the income of every member of the household (from the target population) and any income which may be received by the household as a whole. What is the main source of income in your household? Only one answer possible.

\begin{tabular}{|l|}
\hline MAIN INCOME SOURCES OF YOUR HOUSEHOLD \\
\hline $\begin{array}{l}\text { Employee income, } \\
\text { including bonuses (e.g. vacation or Christmas), tips, extra payments (from e.g. overtime and } \\
\text { shift work), profit sharing }\end{array}$ \\
\hline Income from self-employment or farming, also free-lance work \\
\hline $\begin{array}{l}\text { Pensions, } \\
\text { including old age and widow's pensions, retirement }\end{array}$ \\
\hline $\begin{array}{l}\text { Unemployment / redundancy benefits, } \\
\text { including benefits related to training and sickness allowances }\end{array}$ \\
\hline Rentals and Property income \\
\hline $\begin{array}{l}\text { Current public transfers received, social benefits and grants } \\
\text { including child and family allowances, universal and/or means-tested social assistance and } \\
\text { orphan's pensions, educational grants }\end{array}$ \\
\hline Regular private transfers from persons outside your own household, including alimony \\
\hline $\begin{array}{l}\text { Income from other sources } \\
\text { including reimbursements from taxes and insurances, lottery winnings }\end{array}$ \\
\hline
\end{tabular}




\section{Question 5}

Who is the main income earner of your household?

\begin{tabular}{|l|}
\hline MAIN INCOME EARNER \\
\hline Myself \\
\hline My partner/spouse \\
\hline Myself and my partner \\
\hline My father and/or my mother \\
\hline My child \\
\hline Other member of the household \\
\hline
\end{tabular}

\section{Conclusion}

We developed not a measure for the household's financial situation used for (socio-) economic research like ECHP. But for social surveys, we provide necessary information, so the researcher can assess the reliability of the income measurement by internal checks on the quality of the answers given by the respondents. External checks, comparing income data with data from other sources, are demonstrated by Atkinson and Micklewright (1983).

Our proposed instrument for comparative social survey research (e.g. ESS) consists of five questions. The system of answer categories is adapted to the national circumstances and the income distribution of each country. The outcomes of this query allow classifying surveyed households by socio economic status.

With less interview burden we obtain information relevant to sociological research. Our instrument offers the requirements to measure income detailed enough, because the major characteristics having an impact on the answer quality are controlled during the interview situation.

Table 22: Generalized index of diversity by surveys and response categories for selected countries.

\begin{tabular}{|c|c|c|c|}
\hline & \multicolumn{3}{|c|}{ Data sets and categories } \\
\hline & $\begin{array}{c}\text { ESS with } \\
\text { ESS } \\
\text { categories }\end{array}$ & $\begin{array}{c}\text { ECHP with ESS } \\
\text { categories }\end{array}$ & $\begin{array}{c}\text { ECHP with } \\
\text { proposed } \\
\text { categories }\end{array}$ \\
\hline Germany & 0.937 & 0.919 & 0.960 \\
\hline United Kingdom & 0.956 & 0.927 & 0.985 \\
\hline Italy & 0.936 & 0.907 & 0.958 \\
\hline Luxembourg & 0.912 & 0.881 & 0.982 \\
\hline Portugal & 0.930 & 0.885 & 0.943 \\
\hline Finland & 0.953 & 0.935 & 0.968 \\
\hline
\end{tabular}


Table 23: Coefficients of variation inside each income category for Luxembourg (see annex for the other county's tables).

\begin{tabular}{|c|c|c|c|c|c|c|c|c|}
\hline ESS categories & Mean & Median & Min & $\operatorname{Max}$ & $\begin{array}{l}\text { Std. } \\
\text { Devia- } \\
\text { tion }\end{array}$ & $\begin{array}{c}\% \text { of } \\
\text { Total } \mathrm{N}\end{array}$ & $\mathrm{N}$ & $\begin{array}{c}\text { Coefficient } \\
\text { of } \\
\text { variation }\end{array}$ \\
\hline$-1,800$ & 1279 & 1279 & 1279 & 1279 & & 0.0 & 1 & \\
\hline $1,800-3,600$ & 2643 & 2643 & 2310 & 2975 & 470 & 0.1 & 2 & 17.8 \\
\hline $3,600-6,000$ & 5652 & 5652 & 5652 & 5652 & & 0.0 & 1 & \\
\hline $6,000-12,000$ & 9849 & 10412 & 6544 & 11899 & 1728 & 1.2 & 28 & 17.5 \\
\hline $12,000-18,000$ & 15567 & 15519 & 12137 & 17997 & 1602 & 6.3 & 152 & 10.3 \\
\hline $18,000-24,000$ & 21347 & 21418 & 18022 & 23996 & 1753 & 11.6 & 279 & 8.2 \\
\hline $24,000-30,000$ & 27337 & 27386 & 24023 & 29995 & 1790 & 12.5 & 300 & 6.5 \\
\hline $30,000-36,000$ & 33235 & 33297 & 30037 & 35994 & 1682 & 10.9 & 62 & 5.1 \\
\hline $36,000-6$ & 46251 & 45079 & 36043 & 59996 & 7001 & 33.9 & 16 & 15.1 \\
\hline $60,0 c$ & 061 & 70945 & 60004 & 5 & 8406 & 17.5 & 421 & 11.7 \\
\hline $90,000-120,000$ & 753 & 98923 & 90223 & 117457 & 7536 & 4.5 & 108 & 7.5 \\
\hline $120,000+$ & 153549 & 144181 & 120470 & 289306 & 34912 & 1.6 & 38 & 22.7 \\
\hline Total & 45811 & 39588 & 1279 & 289306 & 26376 & 100.0 & 2408 & \\
\hline $\begin{array}{l}\text { Proposed } \\
\text { categories }\end{array}$ & Mean & Median & Min & $\operatorname{Max}$ & $\begin{array}{c}\text { Std. } \\
\text { Devia- } \\
\text { tion }\end{array}$ & $\begin{array}{c}\% \text { of } \\
\text { Total N }\end{array}$ & $\mathrm{N}$ & $\begin{array}{c}\text { Coefficient } \\
\text { of } \\
\text { variation }\end{array}$ \\
\hline$-10,000 €$ & 6725 & 7139 & 1279 & 9980 & 2684 & 0.6 & 15 & 39.9 \\
\hline $10,000-15,000$ & 13251 & 13386 & 10203 & 14995 & 1441 & 3.2 & 76 & 10.9 \\
\hline $15,000-20,000$ & 17729 & 17848 & 15071 & 19980 & 1447 & 7.1 & 170 & 8.2 \\
\hline $20,000-25,000$ & 22566 & 22608 & 20001 & 24988 & 1350 & 9.9 & 239 & 6.0 \\
\hline $25,000-30,000$ & 27741 & 27874 & 25008 & 29995 & 1521 & 10.9 & 263 & 5.5 \\
\hline $30,000-35,000$ & 32707 & 32747 & 30037 & 34977 & 1386 & 8.9 & 214 & 4.2 \\
\hline $35,000-40,000$ & 37438 & 37422 & 35058 & 39989 & 1364 & 10.0 & 241 & 3.6 \\
\hline $40,000-45,000$ & 42338 & 42161 & 40010 & 44980 & 1475 & 8.9 & 214 & 3.5 \\
\hline $45,000-50,000$ & 47607 & 47595 & 45067 & 49984 & 1527 & 6.3 & 151 & 3.2 \\
\hline $50,000-55,000$ & 52394 & 52256 & 50050 & 54961 & 1491 & 5.5 & 132 & 2.8 \\
\hline $55,000-60,000$ & 57627 & 57475 & 55029 & 59996 & 1555 & 5.2 & 126 & 2.7 \\
\hline $60,000-70,000$ & 64438 & 64188 & 60004 & 69911 & 2768 & 8. & 195 & 4.3 \\
\hline $70,000-80,000$ & 74649 & 74566 & 70058 & 79815 & 2945 & 5. & 133 & 3.9 \\
\hline $80,000-90,000$ & 84346 & 83793 & 80112 & 89955 & 2926 & 3.9 & 93 & 3.5 \\
\hline $90,000-100,000$ & 95179 & 95868 & 90223 & 99681 & 2975 & 2.5 & 61 & 3.1 \\
\hline $100,000-110,000$ & 104660 & 104405 & 100025 & 109924 & 3078 & 1.2 & 29 & 2.9 \\
\hline $110,000+$ & 140628 & 129331 & 110064 & 289306 & 34357 & 2.3 & 56 & 24.4 \\
\hline Total & 45811 & 39588 & 1279 & 289306 & 26376 & 100.0 & 2408 & \\
\hline
\end{tabular}

Our offered system of answer categories consists of three different types of categorical systems and reflects the national income distribution and is at the same coordinated over countries. The result from comparative research becomes meaningful and significant.

Table 22 illustrates the outcomes of our proposed set of questions. The left column reports the dissimilarities of the ESS answer categories in the ESS data; the middle column applies the ESS answer categories to the ECHP data and the right column is calculated on the ECHP data using the proposed answer categories. 
Using ECHP as reliable data on income distributions in observed countries, we obtain higher generalized indexes of diversity by the proposed answer categories adapted to the national context than applying the original ESS income groups to our reference data. In all countries the population of respondents is more equal distributed over our income categories than over the ESS income ranges. In particular, this is true for Luxembourg representing richer countries and for Portugal which stands for poorer nations.

Table 23 compares the net total household incomes of ECHP from Luxembourg inside each answer category. The upper part of the table shows the ESS income brackets. The lower part reports the coefficients of variation inside of our proposed answer categories. Except for the lowest and highest income brackets our system of income groups reduces remarkably the variation inside the categories, the distribution within the groups are closer to the mean income of that category.

\section{References}

[1] Atkinson, A.B. and Brandolini, A. (2001): Promise and pitfalls in the use of 'secondary' data-sets: Income inequality in OECD countries as a case study. Journal of Economic Literature, 3, 771-799.

[2] Atkinson, A.B. and Micklewright J. (1983): On the reliability of income data in the family expenditure survey 1970-1977. Journal of the Royal Statistical Society, 1, 33-61.

[3] Atkinson, A.B., Rainwater, L., and Smeeding, T. (1995): Income Distribution in OECD Countries: The Evidence from the Luxembourg Income Study. Paris: OECD.

[4] CHINTEX (2004): Harmonisation of Panel Surveys and Data Quality, Final Report, Wiesbaden. http://www.destatis.de/chintex/index.htm.

[5] Cowell, F.A., Litchfield, J.A., and Mercader-Prats, M. (1999): Income inequality comparisons with dirty data: The UK and Spain during the 1980s. DARP Discussion Paper no. 45.

[6] Cowell, F.A. and Victoria-Feser, M.P. (1996): Robustness properties of inequality measures. Econometrica, 1, 77-101.

[7] European Commission (1996): European community household panel (ECHP): Volume 1: Survey methodology and implementation. - survey questionnaires, Luxembourg.

[8] European Commission (2002): MISSOC Mutual Information System on Social Protection in the EU Member States and the EEA, Luxembourg. http://europa.eu.int/comm/employment_social/missoc/2002/index_en.htm.

[9] European Commission (2004): MISSOC Mutual Information System on Social Protection. Social protection in the Member States of the European Union, of 
the European Economic Area and in Switzerland. Situation on 1 January 2004, Luxembourg: European Commission. Directorate-General for Employment and Social Affairs.

[10] European Commission/Eurostat (2003): ECHP UDB Description of Variables. Data Dictionary, Codebook and Differences between Countries and Waves. DOC.PAN 166 / 2003-12, Luxembourg.

[11] European Commission/Eurostat (2003): ECHP UDB Construction of Variables. From ECHP Questions to UDB Variables. DOC.PAN 167 / 200312, Luxembourg.

[12] European Social Survey (2002): The European Social Survey. Source Questionnaire (Round 1, 2002). ESS Document Date. 01-08-02. http://www.europeansocialsurvey.org/.

[13] European Social Survey (2002): The European Social Survey. Source Questionnaire (Round1, 2002). TNS ABACUS - Versione Italiana: 19-12-02. http://www.europeansocialsurvey.org/.

[14] European Social Survey (2002): The European Social Survey. Source Show Cards. http://www.europeansocialsurvey.org/.

[15] European Social Survey (2002): The European Social Survey. Project Instructions (PAPI). ESS Document Date. 15-07-02. http://www.europeansocialsurvey.org/.

[16] European Social Survey (2004): The European Social Survey: Round 1. End of grant report. July 2004. http://www.europeansocialsurvey.org/.

[17] Expert Group on Household Income Statistics, The Canberra Group (2001): Final Report and Recommendations. Ottawa: The Canberra Group.

[18] Gabler, S., Häder, S., and Lahiri, P. (1999): A model based justification of Kish's formula for design effects for weighting and clustering. Survey Methodology, 25, 105-106.

[19] Hoffmeyer-Zlotnik, J.H.P. and Warner, U. (1998): Die Messung von Einkommen im nationalen und internationalen Vergleich, ZUMANachrichten, 42, 30-68.

[20] Hoffmeyer-Zlotnik, J.H.P. and Wolf, Ch. (Eds.) (2003): Advances in CrossNational Comparison. A European Working-Book for Demographic and Socio-Economic Variables. New York: Kluwer Academic/Plenum Publisher.

[21] Holst, Ch. (2003): The validity of income measurement in comarative perspective: Non-response and biases. In Hoffmeyer-Zlotnik, J. H.P. and C. Wolf (Eds.): Advances in Cross-National Comparison. A European WorkingBook for Demographic and Socio-Economic Variables. New York: Kluwer Academic/Plenum Publisher: 367-385.

[22] Lyberg, L., Biemer, P., Collins, M., et al. (1997): Survey Measurement and Process Quality, New York: Willey\&Sons. 
[23] Mistiaen, J.A. and Ravallion, M. (2003): Survey compliance and the distribution of income. The world bank development research group poverty team. Policy Research Working Paper 2956.

[24] Nordberg, L., Pentillä, I., and Sandström, S. (2001): A study on the effects of using interviewing versus register data in income distribution analysis with application to the Finnish ECHP survey in 1996, Wiesbaden: CHINTEX working paper No. 1.

[25] Pyy-Martikainen, M., Sisto, J. and Reijo, M. (2004): The ECHP Study in Finland. Quality Report, Helsinki: Statistics Finland - Living Conditions.

[26] Spiess, M. and Goebel, J. (2003): Evaluation of ECHP Imputation Rules. Work Report. Wiesbaden: http://www.destatis.de/chintex/proj_des/wp_7.htm.

[27] Statistisches Bundesamt (ed.) (2004): Demographische Standards. Ausgabe 2004.

http://www.gesis.org/Methodenberatung/Untersuchungsplanung/Standarddem ografie/index.htm.

[28] Warner, Uwe and Hoffmeyer-Zlotnik, Juergen H.P. (2003): How to measure income. In Hoffmeyer-Zlotnik, J. H.P. and C. Wolf (Eds.): Advances in Cross-National Comparison. A European Working-Book for Demographic and Socio-Economic Variables. New York: Kluwer Academic/Plenum Publisher: 307-323.

[29] Van Praag, B., Hagenaars, A., and Van Eck, W. (1983): The influence of classification and observation errors on the meaurement of income inequality. Econometrica, 51, 1093-1108. 


\section{Appendix}

Coefficients of variation inside each income category for the United Kingdom.

\begin{tabular}{|c|c|c|c|c|c|c|c|c|}
\hline $\begin{array}{c}\text { ESS } \\
\text { categories }\end{array}$ & Mean & Median & Min & Max & $\begin{array}{l}\text { Std. } \\
\text { Devia- } \\
\text { tion }\end{array}$ & $\begin{array}{c}\% \text { of } \\
\text { Total } \mathrm{N}\end{array}$ & $\mathrm{N}$ & $\begin{array}{c}\text { Coefficient } \\
\text { of } \\
\text { variation }\end{array}$ \\
\hline$-1,800$ & 798 & 598 & 65 & 1684 & 606 & 0.5 & 22 & 76.0 \\
\hline $1,800-3,600$ & 2460 & 2260 & 1818 & 3542 & 588 & 0.6 & 23 & 23.9 \\
\hline $3,600-6,000$ & 4856 & 4845 & 3626 & 5935 & 688 & 1.4 & 60 & 14.2 \\
\hline $6,000-12,000$ & 9380 & 9613 & 6013 & 11995 & 1733 & 12.4 & 515 & 18.5 \\
\hline $12,000-18,000$ & 14990 & 14981 & 12002 & 17992 & 1740 & 13.9 & 577 & 11.6 \\
\hline $18,000-24,000$ & 20903 & 20837 & 18019 & 23989 & 1754 & 13.3 & 553 & 8.4 \\
\hline $24,000-30,000$ & 26955 & 26942 & 24000 & 29998 & 1709 & 11.8 & 491 & 6.3 \\
\hline $30,000-36,000$ & 32979 & 32984 & 30000 & 35982 & 1776 & 10.7 & 442 & 5.4 \\
\hline $36,000-60,000$ & 45762 & 45161 & 36008 & 59995 & 6597 & 25.7 & 1065 & 14.4 \\
\hline $60,000-90,000$ & 70034 & 68581 & 60003 & 89623 & 7428 & 7.7 & 318 & 10.6 \\
\hline $90,000-120,000$ & 101321 & 100735 & 90426 & 116916 & 7001 & 1.2 & 49 & 6.9 \\
\hline $120,000+$ & 182741 & 143497 & 122860 & 613426 & 102998 & 0.8 & 32 & 56.4 \\
\hline Total & 32562 & 27871 & 65 & 613426 & 25153 & 100.0 & 4147 & \\
\hline $\begin{array}{l}\text { Proposed } \\
\text { categories }\end{array}$ & Mean & Median & Min & Max & $\begin{array}{l}\text { Std. } \\
\text { Devia- } \\
\text { tion }\end{array}$ & $\begin{array}{c}\% \text { of } \\
\text { Total } \mathrm{N}\end{array}$ & $\mathrm{N}$ & $\begin{array}{c}\text { Coefficient } \\
\text { of } \\
\text { variation }\end{array}$ \\
\hline$-5,000 €$ & 2749 & 2794 & 65 & 4948 & 1548 & 1.9 & 77 & 56.3 \\
\hline $5,000-10,000$ & 7894 & 7916 & 5008 & 9994 & 1321 & 7.8 & 323 & 16.7 \\
\hline $10,000-15,000$ & 12444 & 12316 & 10006 & 14981 & 1427 & 12.3 & 509 & 11.5 \\
\hline $15,000-20,000$ & 17499 & 17526 & 15000 & 19994 & 1440 & 11.7 & 485 & 8.2 \\
\hline $20,000-25,000$ & 22390 & 22449 & 20032 & 24990 & 1420 & 10.3 & 428 & 6.3 \\
\hline $25,000-30,000$ & 27384 & 27258 & 25006 & 29998 & 1465 & 10.1 & 419 & 5.4 \\
\hline $30,000-35,000$ & 32403 & 32242 & 30000 & 34974 & 1425 & 8.7 & 361 & 4.4 \\
\hline $35,000-40,000$ & 37351 & 37288 & 35000 & 39974 & 1437 & 8.3 & 344 & 3.8 \\
\hline $40,000-45,000$ & 42339 & 42239 & 40006 & 44969 & 1351 & 6.3 & 261 & 3.2 \\
\hline $45,000-50,000$ & 47377 & 47303 & 45006 & 49974 & 1478 & 6.0 & 249 & 3.1 \\
\hline $50,000-55,000$ & 52308 & 52158 & 50013 & 54974 & 1490 & 4.1 & 169 & 2.8 \\
\hline $55,000-60,000$ & 57556 & 57492 & 55006 & 59995 & 1518 & 3.0 & 123 & 2.6 \\
\hline $60,000-70,000$ & 64689 & 64590 & 60003 & 69890 & 3030 & 4.3 & 180 & 4.7 \\
\hline $70,000+$ & 97895 & 81948 & 70115 & 613426 & 53603 & 5.3 & 219 & 54.8 \\
\hline Total & 32562 & 27871 & 65 & 613426 & 25153 & 100.0 & 4147 & \\
\hline
\end{tabular}


Coefficients of variation inside each income category for Germany.

\begin{tabular}{|c|c|c|c|c|c|c|c|c|}
\hline ESS categories & Mean & Median & Min & $\operatorname{Max}$ & $\begin{array}{l}\text { Std. } \\
\text { Devia- } \\
\text { tion }\end{array}$ & $\begin{array}{c}\% \text { of } \\
\text { Total } \mathrm{N}\end{array}$ & $\mathrm{N}$ & $\begin{array}{c}\text { Coefficient } \\
\text { of } \\
\text { variation }\end{array}$ \\
\hline$-1,800$ & 854 & 967 & 109 & 1485 & 695 & 0.1 & . & 81.4 \\
\hline $1,800-3,600$ & 3023 & 3080 & 2153 & 3577 & 413 & 0.4 & 19 & 13.7 \\
\hline $3,600-6,000$ & 5000 & 5093 & 3602 & 5969 & 699 & 1.0 & 47 & 14.0 \\
\hline $6,000-12,000$ & 9373 & 9596 & 6073 & 11994 & 1620 & 9.4 & 438 & 17.3 \\
\hline $12,000-18,000$ & 15089 & 15263 & 12010 & 17996 & 1723 & 16.0 & 749 & 11.4 \\
\hline $18,000-24,000$ & 21027 & 21067 & 18002 & 23970 & 1679 & 16.6 & 778 & 8.0 \\
\hline $24,000-30,000$ & 26895 & 26939 & 24002 & 29997 & 1693 & 18.5 & 866 & 6.3 \\
\hline $30,000-36,000$ & 32957 & 32959 & 30000 & 35984 & 1697 & 14.3 & 668 & 5.2 \\
\hline $36,000-60,000$ & 44104 & 42842 & 36000 & 59982 & 6061 & 20.0 & 934 & 13.7 \\
\hline $60,000-90,000$ & 70122 & 68313 & 60112 & 89147 & 7768 & 3.0 & 142 & 11.1 \\
\hline $90,000-120,000$ & 99249 & 98011 & 90571 & 114920 & 7110 & 0.4 & 18 & 7.2 \\
\hline $120,000+$ & 174774 & 137054 & 121811 & 428668 & 86250 & 0.3 & 13 & 49.3 \\
\hline Total & 28359 & 26076 & 109 & 428668 & 17176 & 100.0 & 4675 & \\
\hline $\begin{array}{l}\text { Propos } \\
\text { categor }\end{array}$ & Mean & ledian & Min & $\operatorname{Max}$ & $\begin{array}{l}\text { Std. } \\
\text { Devia- } \\
\text { tion }\end{array}$ & $\begin{array}{c}\% \text { of } \\
\text { Total } \mathrm{N}\end{array}$ & $\mathrm{N}$ & $\begin{array}{c}\text { Coefficient } \\
\text { of } \\
\text { variation }\end{array}$ \\
\hline$-5,000 €$ & 3481 & 3534 & 10 & 4 & 1056 & 0.9 & 42 & 30.3 \\
\hline 000 & 8043 & 8265 & 5009 & 9980 & 1358 & 6.2 & 289 & 16.9 \\
\hline $10,000-15,000$ & 12618 & 12677 & 10005 & 14973 & 1418 & 11.1 & 520 & 11.2 \\
\hline 15,00 & 17377 & 17275 & 15 & 72 & 1408 & 13.6 & 638 & 8.1 \\
\hline $20,000-25,000$ & 22499 & 22425 & 20000 & 24999 & 1473 & 15.1 & 70 & 6.5 \\
\hline $25,000-30,000$ & 27439 & 27446 & 25025 & 29997 & 1374 & 15.1 & 706 & 5.0 \\
\hline $30,000-35,000$ & 32519 & 32556 & 30000 & 34976 & 1433 & 12.2 & 570 & 4.4 \\
\hline $35,000-40,000$ & 37288 & 37186 & 35005 & 39988 & 1445 & 8.6 & 400 & 3.9 \\
\hline $40,000-45,000$ & 42285 & 42254 & 40006 & 44976 & 1334 & 5.6 & 260 & 3.2 \\
\hline $45,000-50,000$ & 47264 & 47157 & 45023 & 49995 & 1500 & 4.2 & 195 & 3.2 \\
\hline $50,000-55,000$ & 52281 & 52062 & 50008 & 54890 & 1376 & 2.5 & 117 & 2.6 \\
\hline $55,000-60,000$ & 57174 & 57077 & 55047 & 59982 & 1383 & 1.3 & 60 & 2.4 \\
\hline $60,000-65,000$ & 64060 & 63927 & 60112 & 69557 & 2706 & 1.7 & 78 & 4.2 \\
\hline $70,000+$ & 94939 & 80960 & 70068 & 428668 & 45470 & 2.0 & 95 & 47.9 \\
\hline otal & 28359 & 26076 & 109 & 428668 & 17176 & 100.0 & 4675 & \\
\hline
\end{tabular}


Coefficients of variation inside each income category for Finland.

\begin{tabular}{|c|c|c|c|c|c|c|c|c|}
\hline ESS categories & Mean & Median & Min & $\operatorname{Max}$ & $\begin{array}{l}\text { Std. } \\
\text { Devia- } \\
\text { tion }\end{array}$ & $\begin{array}{c}\% \text { of } \\
\text { Total } \mathrm{N}\end{array}$ & $\mathrm{N}$ & $\begin{array}{c}\text { Coefficient } \\
\text { of } \\
\text { variation }\end{array}$ \\
\hline$-1,800$ & 1187 & 1296 & 168 & 1767 & 503 & 1.0 & 29 & 42.4 \\
\hline $1,800-3,600$ & 2734 & 2690 & 1870 & 3585 & 516 & 1.3 & 40 & 18.9 \\
\hline $3,600-6,000$ & 4917 & 5064 & 3622 & 5968 & 695 & 2.5 & 75 & 14.1 \\
\hline $6,000-12,000$ & 9043 & 9011 & 6105 & 11974 & 1616 & 14.5 & 437 & 17.9 \\
\hline $12,000-18,000$ & 15197 & 15288 & 12007 & 17991 & 1680 & 16.7 & 503 & 11.1 \\
\hline $18,000-24,000$ & 20827 & 20674 & 18009 & 23966 & 1697 & 15.3 & 461 & 8.1 \\
\hline $24,000-30,000$ & 27001 & 27104 & 24002 & 29991 & 1679 & 13.7 & 413 & 6.2 \\
\hline $30,000-36,000$ & 32923 & 32860 & 30008 & 35989 & 1722 & 12.1 & 365 & 5.2 \\
\hline $36,000-60,000$ & 43888 & 42498 & 36002 & 59787 & 6198 & 18.9 & 569 & 14.1 \\
\hline $60,000-90,000$ & 69464 & 67030 & 60004 & 86834 & 7734 & 3.0 & 91 & 11.1 \\
\hline $90,000-120,000$ & 97419 & 95186 & 91358 & 114560 & 6805 & 0.5 & 15 & 7.0 \\
\hline $120,000_{+}$ & 210764 & 150219 & 121424 & 654755 & 142371 & 0.5 & 15 & 67.6 \\
\hline Total & 26815 & 23386 & 168 & 654755 & 22654 & 100.0 & 3013 & \\
\hline $\begin{array}{l}\text { Proposed } \\
\text { categories }\end{array}$ & Mean & Median & Min & $\operatorname{Max}$ & $\begin{array}{l}\text { Std. } \\
\text { Devia- } \\
\text { tion }\end{array}$ & $\begin{array}{c}\% \text { of } \\
\text { Total } \mathrm{N}\end{array}$ & $\mathrm{N}$ & $\begin{array}{c}\text { Coefficient } \\
\text { of } \\
\text { variation }\end{array}$ \\
\hline$-5,000 €$ & 2857 & 2962 & 168 & 4930 & 1313 & 3.5 & 106 & 46.0 \\
\hline $0-10,000$ & 7794 & 7859 & 5064 & 8 & 1294 & 10.9 & 327 & 16.6 \\
\hline 15,000 & 12521 & 12621 & 10003 & 14992 & 1524 & 12.3 & 372 & 12.2 \\
\hline $15,000-20,000$ & 17462 & 17465 & 15010 & 19999 & 1477 & 15.0 & 451 & 8.5 \\
\hline $20,000-25,000$ & 22393 & 22295 & 20000 & 24992 & 1478 & 11.9 & 358 & 6.6 \\
\hline $25,000-30,000$ & 27500 & 27558 & 25004 & 29991 & 1368 & 11.4 & 344 & 5.0 \\
\hline $30,000-35,000$ & 32560 & 32467 & 30008 & 34995 & 1516 & 10.6 & 320 & 4.7 \\
\hline $35,000-40,000$ & 37513 & 37516 & 35019 & 39986 & 1398 & 8.5 & 256 & 3.7 \\
\hline $40,000-45,000$ & 42410 & 42491 & 40001 & 44969 & 1434 & 4.8 & 145 & 3.4 \\
\hline $45,000-50,000$ & 47454 & 47422 & 45011 & 49968 & 1445 & 3.5 & 105 & 3.0 \\
\hline $50,000-55,000$ & 52135 & 52053 & 50025 & 54971 & 1420 & 2.2 & 67 & 2.7 \\
\hline $55,000-60,000$ & 57101 & 56730 & 55401 & 59787 & 1304 & 1.4 & 41 & 2.3 \\
\hline $60,000-65,000$ & 63857 & 63805 & 60004 & 69007 & 2562 & 1.8 & 54 & 4.0 \\
\hline $70,000+$ & 111876 & 84840 & 70277 & 654755 & 85143 & 2.2 & 67 & 76.1 \\
\hline Total & 26815 & 23386 & 168 & 654755 & 22654 & 100.0 & 3013 & \\
\hline
\end{tabular}


Coefficients of variation inside each income category for Italy.

\begin{tabular}{|c|c|c|c|c|c|c|c|c|}
\hline ESS categories & Mean & Median & Min & $\operatorname{Max}$ & $\begin{array}{l}\text { Std. } \\
\text { Devia- } \\
\text { tion }\end{array}$ & $\begin{array}{c}\% \text { of } \\
\text { Total } \mathrm{N}\end{array}$ & $\mathrm{N}$ & $\begin{array}{c}\text { Coefficient } \\
\text { of } \\
\text { variation }\end{array}$ \\
\hline$-1,800$ & 905 & 775 & 207 & 1653 & 446 & 1.0 & 45 & 49.2 \\
\hline $1,800-3,600$ & 2680 & 2582 & 1808 & 3572 & 532 & 1.3 & 60 & 19.9 \\
\hline $3,600-6,000$ & 4981 & 4958 & 3615 & 5991 & 590 & 5.4 & 249 & 11.8 \\
\hline $6,000-12,000$ & 9272 & 9296 & 6012 & 11989 & 1705 & 22.8 & 1045 & 18.4 \\
\hline $12,000-18,000$ & 14729 & 14706 & 12000 & 17999 & 1712 & 24.2 & 1108 & 11.6 \\
\hline $18,000-24,000$ & 20873 & 20786 & 18009 & 23993 & 1714 & 16.3 & 747 & 8.2 \\
\hline $24,000-30,000$ & 26842 & 26752 & 24015 & 29995 & 1738 & 12.9 & 589 & 6.5 \\
\hline $30,000-36,000$ & 32560 & 32359 & 30006 & 35945 & 1622 & 7.1 & 325 & 5.0 \\
\hline $36,000-60,000$ & 43727 & 640 & 36080 & 59817 & 6495 & 8.2 & 375 & 14.9 \\
\hline $60,000-9$ & 69035 & 68129 & 60871 & 83809 & 6763 & 0.6 & 28 & 9.8 \\
\hline $90,000-120,000$ & 100256 & 95297 & 91534 & 119818 & 9897 & 0.2 & 9 & 9.9 \\
\hline $120,000_{+}$ & 158924 & 163200 & 120218 & 193353 & 36754 & 0.1 & 3 & 23.1 \\
\hline Total & 19451 & 16527 & 207 & 193353 & 12757 & 100.0 & 4583 & \\
\hline $\begin{array}{l}\text { Proposed } \\
\text { categories }\end{array}$ & Mean & Median & Min & $\operatorname{Max}$ & $\begin{array}{l}\text { Std. } \\
\text { Devia- } \\
\text { tion }\end{array}$ & $\begin{array}{c}\% \text { of } \\
\text { Total } \mathrm{N}\end{array}$ & $\mathrm{N}$ & $\begin{array}{c}\text { Coefficient } \\
\text { of } \\
\text { variation }\end{array}$ \\
\hline$-2,500 €$ & 1308 & 1291 & 207 & 2493 & 700 & 1.5 & 67 & 53.5 \\
\hline $2,500-5,000$ & 4208 & 4524 & 2516 & 4998 & 752 & 3.8 & 174 & 17.9 \\
\hline $5,000-7,500$ & 6368 & 6249 & 5035 & 7497 & 751 & 7.3 & 333 & 11.8 \\
\hline $7,500-10,000$ & 8895 & 8986 & 7511 & 9984 & 704 & 9.3 & 427 & 7.9 \\
\hline $10,000-12,500$ & 11364 & 11362 & 10003 & 12498 & 750 & 11.8 & 540 & 6.6 \\
\hline $12,500-15,000$ & 13750 & 13645 & 12529 & 14977 & 704 & 10.3 & 473 & 5.1 \\
\hline $15,000-20,000$ & 17304 & 17212 & 15002 & 19999 & 1481 & 16.6 & 762 & 8.6 \\
\hline $20,000-25,000$ & 22417 & 22311 & 20013 & 24997 & 1463 & 12.9 & 590 & 6.5 \\
\hline $25,000-30,000$ & 27386 & 27269 & 25005 & 29995 & 1468 & 10.4 & 477 & 5.4 \\
\hline $30,000-35,000$ & 32280 & 32137 & 30006 & 34964 & 1400 & 6.5 & 297 & 4.3 \\
\hline $35,000-40,000$ & 37430 & 37225 & 35038 & 39896 & 1376 & 3.9 & 181 & 3.7 \\
\hline $40,000-45,000$ & 42227 & 41768 & 40025 & 44945 & 1461 & 1.7 & 78 & 3.5 \\
\hline $45,000-50,000$ & 47419 & 47514 & 45056 & 49948 & 1393 & 1.6 & 73 & 2.9 \\
\hline $50,000-55,000$ & 52003 & 51995 & 50027 & 54744 & 1425 & 0.8 & 37 & 2.7 \\
\hline $55,000-60,000$ & 57008 & 56543 & 55056 & 59817 & 1420 & 0.7 & 34 & 2.5 \\
\hline $60,000_{+}$ & 82802 & 71607 & 60871 & 193353 & 27805 & 0.9 & 40 & 33.6 \\
\hline otal & 19451 & 16527 & 207 & 193353 & 12757 & 100.0 & 4583 & \\
\hline
\end{tabular}


Coefficients of variation inside each income category for Portugal.

\begin{tabular}{|c|c|c|c|c|c|c|c|c|}
\hline ESS categories & Mean & Median & Min & $\operatorname{Max}$ & $\begin{array}{l}\text { Std. } \\
\text { Devia- } \\
\text { tion }\end{array}$ & $\begin{array}{c}\% \text { of } \\
\text { Total } N\end{array}$ & $\mathrm{~N}$ & $\begin{array}{l}\text { Coefficient } \\
\text { of variation }\end{array}$ \\
\hline$-1,800$ & 1067 & 1008 & 5 & 1796 & 556 & 2.4 & 95 & 52.1 \\
\hline $1,800-3,600$ & 2744 & 2734 & 1809 & 3591 & 489 & 10.3 & 417 & 17.8 \\
\hline $3,600-6,000$ & 4834 & 4888 & 3601 & 5999 & 694 & 17.0 & 687 & 14.4 \\
\hline $6,000-12,000$ & 8924 & 8851 & 6006 & 11997 & 1736 & 30.9 & 1248 & 19.5 \\
\hline $12,000-18,000$ & 14547 & 14387 & 12002 & 17962 & 1666 & 20.0 & 810 & 11.5 \\
\hline $18,000-24,000$ & 20613 & 20383 & 18001 & 23986 & 1702 & 9.8 & 397 & 8.3 \\
\hline $24,000-30,000$ & 26601 & 26525 & 24005 & 29964 & 1692 & 4.5 & 183 & 6.4 \\
\hline $30,000-36,000$ & 32669 & 32594 & 30028 & 35970 & 1655 & 2.1 & 83 & 5.1 \\
\hline $36,000-60,000$ & 44434 & 42654 & 36055 & 59597 & 6844 & 2.5 & 100 & 15.4 \\
\hline $60,000-90,000$ & 70844 & 67513 & 60772 & 89750 & 8665 & 0.5 & 20 & 12.2 \\
\hline $90,000-120,000$ & 90073 & 90073 & 90073 & 90073 & & 0.0 & 1 & \\
\hline $120,000+$ & 190826 & 190826 & 190826 & 190826 & & 0.0 & 1 & \\
\hline Total & 12220 & 9799 & 5 & 190826 & 10317 & 100.0 & 4042 & \\
\hline $\begin{array}{l}\text { Proposed } \\
\text { categories }\end{array}$ & Mean & Median & Min & $\operatorname{Max}$ & $\begin{array}{l}\text { Std. } \\
\text { Devia- } \\
\text { tion }\end{array}$ & $\begin{array}{c}\% \text { of } \\
\text { Total } \mathrm{N}\end{array}$ & $\mathrm{N}$ & $\begin{array}{l}\text { Coefficient } \\
\text { of variation }\end{array}$ \\
\hline$-2,500 €$ & 1748 & 1891 & 5 & 2494 & 684 & 5.8 & 235 & 39.1 \\
\hline $2,500-5,000$ & 3760 & 3801 & 2506 & 4993 & 739 & 16.3 & 658 & 19.7 \\
\hline $5,000-7,500$ & 6143 & 6042 & 5003 & 7493 & 728 & 15.7 & 636 & 11.8 \\
\hline $7,500-10,000$ & 8742 & 8745 & 7502 & 9992 & 728 & 13.1 & 528 & 8.3 \\
\hline $10,000-12,500$ & 11264 & 11226 & 10003 & 12499 & 713 & 12.0 & 485 & 6.3 \\
\hline $12,500-15,000$ & 13706 & 13733 & 12500 & 14994 & 741 & 10.1 & 407 & 5.4 \\
\hline $15,000-20,000$ & 17248 & 17109 & 15003 & 19987 & 1462 & 11.6 & 469 & 8.5 \\
\hline $20,000-25,000$ & 22192 & 22025 & 20008 & 24983 & 1507 & 7.0 & 281 & 6.8 \\
\hline $25,000-30,000$ & 27279 & 27042 & 25022 & 29964 & 1375 & 3.4 & 138 & 5.0 \\
\hline $30,000-35,000$ & 32378 & 32472 & 30028 & 34929 & 1462 & 1.9 & 75 & 4.5 \\
\hline $35,000-40,000$ & 37257 & 37275 & 35016 & 39904 & 1394 & 1.0 & 42 & 3.7 \\
\hline $40,000-45,000$ & 42299 & 42065 & 40104 & 44914 & 1423 & 0.7 & 28 & 3.4 \\
\hline $45,000-50,000$ & 47513 & 47702 & 45220 & 49441 & 1289 & 0.3 & 13 & 2.7 \\
\hline $50,000-55,000$ & 51908 & 51575 & 50373 & 54968 & 1474 & 0.3 & 14 & 2.8 \\
\hline $55,000-60,000$ & 57549 & 57309 & 55334 & 59597 & 1427 & 0.3 & 11 & 2.5 \\
\hline $60,000+$ & 77172 & 69326 & 60772 & 190826 & 27002 & 0.5 & 22 & 35.0 \\
\hline Total & 12220 & 9799 & 5 & 190826 & 10317 & 100.0 & 4042 & \\
\hline
\end{tabular}

